ZBIGNIEW ZiOŁo

Uniwersytet Pedagogiczny, Kraków, Polska

\title{
Wpływ kryzysu na ksztaltowanie struktury przestrzennej przemysłu
}

\section{Impact of the crisis on the formation of the spatial structure of the industry}

Streszczenie: W pracy na tle ekonomicznych reguł rozwoju (mikroekonomicznych, mezoekonomicznych, makroekonomicznych, megaekonomicznych i reguł rozwoju światowego) przedstawiono: pojęcie struktury przestrzennej przemysłu, podstawowe mierniki potencjału przemysłowego, funkcje przedsiębiorstw w strukturze przestrzennej przemysłu oraz zachowania przedsiębiorstw podczas kryzysu. Rozważania modelowe częściowo zilustrowano przykładami przemian przemysłu w przestrzeni krajowej.

\begin{abstract}
The paper, on the background of the economic development rules (micro-, meso-, macroand mega-economic and development of the world), presents: the concept of the spatial structure of the industry, basic indicators of industrial potential, corporate functions in the spatial structure of the industry and the behaviour of enterprises in the conditions of crisis. Model considerations is partly illustrated with the examples of industrial change at the national level.
\end{abstract}

Słowa kluczowe: kryzys gospodarczy; przedsiębiorstwo przemysłowe; struktura przestrzenna przemysłu

Keywords: economic crisis; industrial company; spatial structure of the industry

\section{WSTĘP}

Procesy przemian gospodarczych, społecznych i kulturowych dokonują się pod wpływem nakładających się reguł ekonomicznych oraz przyjmowanych zasad polityki, które z różnym nasileniem oddziałują na procesy zróżnicowania poziomu rozwoju i jakości życia. Realizują się one w różnych skalach przestrzennych, od skali światowej, poprzez skale kontynentów, grup państw, poszczególnych krajów, regionów i układów lokalnych. W układach przestrzennych procesy te warunkują także różnego typu wyznawane ideologie, poziom rozwoju społeczno-gospodarczego i kulturowego, w tym jakość zasobów kultury duchowej, a także 
elementów środowiska przyrodniczego (Zioło, 2003a). Współcześnie ważnym czynnikiem zakłócającym dotychczasowy proces rozwoju jest kryzys ekonomiczny, który zmienia zasady funkcjonowania zarówno przedsiębiorstw przemysłowych, instytucji, zachowań społeczeństwa, jak i jednostek ludzkich. Prowadzi on także do przemian uwarunkowań układów przestrzennych, które wynikają z konieczności dostosowania ich elementów do nowych sytuacji wywołanych kryzysem. Przejawia się to w różnicowaniu ich potencjału społeczno-gospodarczego i kulturowego, w wyniku czego następują przekształcenia struktur funkcjonalnych.

$\mathrm{Na}$ tym tle przedmiotem naszych rozważań jest zarysowanie problematyki wpływu kryzysu gospodarczego na kształtowanie struktury przestrzennej przemysłu. W nowych warunkach gospodarowania oraz przy nasilających się procesach globalizacji i związanych z nimi procesach integracji europejskiej konieczne są próby poszukiwań nowych wzrostów analitycznych dotyczących kształtowania struktury przestrzennej przemysłu w różnej skali układów przestrzennych. W analizach tych należy także zwracać uwagę na reguły ekonomicznego rozwoju odnoszące się zwłaszcza do poszczególnych przedsiębiorstw, sektorów oraz gospodarki krajowej i międzynarodowej. Nawiązujemy tu do wcześniejszych prac autora związanych z modelowaniem struktur przestrzennych przemysłu, analizą uwarunkowań rozwoju przedsiębiorczości podczas kryzysu gospodarczego, a także dorobku Komisji Geografii Przemysłu Polskiego Towarzystwa Geograficznego (Zioło, 1980a; Zioło, 1980b; Zioło, 1997; Zioło, 1999; Zioło, 2011; Zioło, 2013; Zioło, Rachwał, 2011; Rachwał, 2011).

\section{REGUŁY ROZWOJU EKONOMICZNEGO A KRYZYS GOSPODARCZY}

Na gruncie nauk ekonomicznych i ekonomiczno-geograficznych problematyka kryzysu gospodarczego jest szczególnie aktualna i będzie wymagać dalszych pogłębionych studiów, w celu wyjaśnienia jego mechanizmów i skutków dla gospodarki światowej, poszczególnych kontynentów, krajów, regionów, a także układów lokalnych. Podejmowane są już liczne prace dotyczące genezy, czynników oraz działań na rzecz ograniczania jego negatywnych skutków gospodarczych, społecznych i kulturowych. Współczesny kryzys gospodarczy, jak powszechnie wiadomo, zainicjował kryzys finansowy, który wywarł negatywne piętno na gospodarce światowej, a w konsekwencji także gospodarce poszczególnych krajów i regionów. Wynika to z faktu, iż nasilające się procesy globalizacji gospodarczej, społecznej i kulturowej wykształcają coraz silniejsze powiązania funkcjonalne, prowadzące do integracji przestrzeni światowej.

Generalnie kryzys gospodarczy wywołuje zachwianie pewnej równowagi zachodzącej między rozmiarami produkcji a chłonnością rynku. Na tym tle wykształciły się odmienne szkoły ekonomiczne opowiadające się za liberalizacją gospodarki i rynku, którego mechanizmy same doprowadzą do równowagi gospodarczej, oraz szkoły wskazujące na konieczność regulowania procesów rynkowych przez państwo. M. Kalecki (1979) przyjmuje, że najważniejszymi wadami systemu społeczno-ekonomicznego są niezdolność do pełnego zatrudnienia oraz niesprawiedliwy podział bogactwa i dochodów. Negatywnym tego skutkiem jest 
ograniczony popyt znacznej części społeczeństwa. Stwarza to barierę dla rozwoju masowej produkcji wyrobów zaspokajającej potrzeby znacznej części mniej opłacanego, a w konsekwencji mniej zamożnego społeczeństwa. Dobrobyt społeczeństwa pochodzi z pracy i produkcji dóbr, za wytwarzanie których pracownicy mają otrzymywać odpowiednie wynagrodzenia. Dlatego należy do minimum ograniczać te sektory (np. administrację, nadmiernie liczne rady nadzorcze, parlamentarzystów), które nie mają istotnego wpływu na rzeczywiste efekty gospodarowania. W. Szymański (2001) źródła obecnego kryzysu upatruje w niesprawności rynku jako regulatora procesów rozwojowych. G. Soros (2008) uważa, że rynkiem zarządza nastrój inwestorów, który kształtuje się pod wpływem strachu i chciwości. W konsekwencji sam rynek nie dąży do równowagi, natomiast w sytuacji kryzysowej państwo powinno go stabilizować. Już A. Smith (1954) zakładał, że człowiek musi żyć z efektów swojej pracy, czyli jego płaca ma wystarczyć na utrzymanie siebie i rodziny.

Jako istotne źródło współczesnego kryzysu uważa się także rozliczenia w dolarach, które są pewnym pieniądzem symbolicznym, w niewielkim stopniu opartym na parytecie złota, stąd mogą nim dowolnie manipulować systemy bankowe i giełdy, co daje pewne korzyści gospodarce amerykańskiej. J.M. Keynes (1956) w celu ograniczenia negatywnych zjawisk na rynkach finansowych, związanych $\mathrm{z}$ manipulowaniem pieniądzem, proponował wprowadzenie pieniądza międzynarodowego, wyemitowanego przez Międzynarodowy Fundusz Walutowy, który będzie posiadał stały kurs i będzie oparty na parytecie złota.

W procesie historycznego rozwoju i współcześnie pod wpływem procesu koncentracji kapitału powstają coraz potężniejsze korporacje światowe, które znacznie przewyższają potencjał ekonomiczny mniejszych państw. Dążąc do pełnej swobody w zakresie przepływu kapitału i produktów, w znaczącym stopniu osłabiają rolę wielu krajów w zakresie kreowania własnej polityki rozwoju społeczno-gospodarczego.

Wydaje się, że można przyjąć hipotezę, iż współczesna sytuacja kryzysowa wynika w znacznym stopniu z nakładania się różnych reguł rozwoju, odnoszących się do podmiotów gospodarczych, społeczeństwa oraz całej gospodarki, które generują pewne konflikty. Dlatego ważnym problemem jest zarysowanie tego zjawiska w celu precyzyjniejszego wyjaśniania sytuacji kryzysowych w różnych skalach układów przestrzennych. Zjawiska kryzysowe pojawiają się w wyniku oddziaływania różnych reguł rozwoju ekonomicznego, które zakładają różne cele gospodarowania dla rozwoju: podmiotów gospodarczych, struktur branżowych i regionalnych, układów krajowych, grupy krajów czy gospodarki światowej.

Podmioty gospodarcze kształtują się w wyniku działania reguł mikroekonomicznych, a głównym celem ich działalności jest maksymalizacja zysków. Generalnie dokonuje się to poprzez obniżanie kosztów wytwarzania, a szczególnie kosztów pracy. W tym celu podejmują one samodzielnie decyzje, kierując się własnym interesem i związanym z tym ryzykiem.

Gospodarka regionalna czy sektorowa formuje się wg reguł mezoekonomicznych i uwzględnia interesy określonych systemów złożonych z różnych podmiotów gospodarczych, instytucji, społeczeństwa, określonego sektora gospodarczego lub branży. W strukturze tego typu systemów funkcjonują różnorodne elementy spełniające określone funkcje, między którymi zachodzą pewne relacje prowadzące do pobudzania ich wzajemnego wzrostu, ale często także nasilają się między nimi relacje konkurencyjne. Zachodzi więc 
konieczność godzenia bardzo różnych interesów, mając na uwadze możliwości wzrostu efektywności funkcjonowania i rozwoju zarówno danego układu przestrzennego, jak i sektora gospodarki.

Kształtowanie gospodarki danego kraju dokonuje się w wyniku wykorzystywania reguł makroekonomicznymi. Szczególna ich rola związana jest z: generowaniem coraz wyższego dochodu narodowego, dążeniem do jego efektywnego podziału, w racjonalnym stopniu wpływaniem na zwiększanie budżetu państwa, dbaniem o racjonalny obieg pieniądza, ograniczaniem rozmiarów inflacji i bezrobocia, dbaniem o poprawny bilans płatniczy i in.

Według reguł megaekonomicznych kształtuje się gospodarka grupy krajów, w tym Unii Europejskiej. Ważnym zadaniem jest utrzymanie jej konkurencyjności w stosunku do rozwijających się światowych centrów wzrostu (Stany Zjednoczone, Japonia) oraz nowych rozwijających się centrów (Chiny, Indie, Rosja, Brazylia). Podejmowane działania mają na celu dążenie do systematycznego podnoszenia poziomu gospodarczego poszczególnych krajów, nasilenie powiązań gospodarczych, osłabienie stopnia zróżnicowania gospodarczego i dążenie do wyrównywania dysproporcji rozwojowych między krajami.

Reguły ekonomii światowej prowadzą do globalnego rozwoju, przy zachowaniu zasad równoważenia rozwoju gospodarczego, społecznego i kulturowego, ograniczaniu negatywnych skutków konfliktów wojskowych i negatywnych procesów prowadzących do polaryzacji światowej przestrzeni, ograniczaniu negatywnych skutków rozwoju gospodarczego (np. zmian klimatycznych, rozprzestrzeniania się chorób, nadmiernej eksploatacji zasobów leśnych i pozostałych elementów środowiska przyrodniczego, przez likwidację barier utrudniających podnoszenie jakości i wyrównywanie poziomu życia ludności, a także zmniejszanie ubóstwa w skali światowej).

W procesie rozwoju gospodarczego, społecznego i kulturowego oraz różnej skali układów przestrzennych zaznaczają się określone relacje aktywne i pasywne zachodzące między regułami rozwoju ekonomicznego (tab. 1). Wpływ reguł mikroekonomicznych: na reguły mezoekonomiczne określa $\left[\mathrm{x}_{12}\right]$, na reguły makroekonomiczne $-\left[\mathrm{x}_{13}\right]$, na reguły megaekonomiczne $-\left[\mathrm{x}_{14}\right]$ i na reguły ekonomii światowej $-\left[\mathrm{x}_{15}\right]$. Również na reguły mikroekonomiczne oddziałują pozostałe reguły rozwoju, które opisują kolejne relacje: $\left.\left[\mathrm{x}_{21}\right],\left[\mathrm{x}_{31}\right], \mathrm{x}_{41}\right] \mathrm{i}\left[\mathrm{x}_{51}\right]$.

Tab. 1. Relacje między regułami ekonomicznymi

\begin{tabular}{|l|c|c|c|c|c|c|}
\hline \multirow{2}{*}{ Reguły ekonomiczne } & mikro- & mezo- & makro- & mega- & $\begin{array}{c}\text { reguły } \\
\text { światowe }\end{array}$ \\
\cline { 3 - 7 } & $\mathrm{X}_{1}$ & $\mathrm{X}_{2}$ & $\mathrm{X}_{3}$ & $\mathrm{X}_{4}$ & $\mathrm{X}_{5}$ \\
\hline mikro- & $\mathrm{X}_{1}$ & $\mathrm{X}_{11}$ & $\mathrm{X}_{12}$ & $\mathrm{X}_{13}$ & $\mathrm{X}_{14}$ & $\mathrm{X}_{15}$ \\
\hline mezo- & $\mathrm{X}_{2}$ & $\mathrm{X}_{21}$ & $\mathrm{X}_{22}$ & $\mathrm{X}_{23}$ & $\mathrm{X}_{24}$ & $\mathrm{X}_{25}$ \\
\hline makro- & $\mathrm{X}_{3}$ & $\mathrm{X}_{31}$ & $\mathrm{X}_{32}$ & $\mathrm{X}_{33}$ & $\mathrm{X}_{34}$ & $\mathrm{X}_{35}$ \\
\hline mega- & $\mathrm{X}_{4}$ & $\mathrm{X}_{41}$ & $\mathrm{X}_{42}$ & $\mathrm{X}_{43}$ & $\mathrm{X}_{44}$ & $\mathrm{X}_{45}$ \\
\hline $\begin{array}{l}\text { reguły } \\
\text { światowe }\end{array}$ & $\mathrm{X}_{5}$ & $\mathrm{X}_{51}$ & $\mathrm{X}_{52}$ & $\mathrm{X}_{53}$ & $\mathrm{X}_{54}$ & $\mathrm{X}_{55}$ \\
\hline
\end{tabular}

Źródło: opracowanie własne 
Podobnie relacje aktywne i pasywne zachodzą między pozostałymi regułami rozwoju (mezoekonomicznymi, makroekonomicznymi, megaekonomicznymi oraz regułami rozwoju światowego).

W realnej gospodarce relacje między poszczególnymi regułami ekonomicznymi mogą prowadzić do pobudzania rozwoju gospodarczego, ale także mogą zachodzić między nimi określone konflikty. Wynikają one z różnych celów działalności podmiotów gospodarczych, celów regionalnych, krajowych czy światowych. Przedsiębiorstwa np. z reguły chciałyby płać jak najniższe podatki, natomiast układy krajowe chciałyby mieć jak największe wpływy do budżetu z tytułu podatków. Podobnie kraje Unii Europejskiej chciałyby otrzymywać jak najwyższe dotacje na rozwój działalności gospodarczej, a równocześnie jak najmniej wpłacać do unijnego budżetu.

Działania na rzecz rozwoju gospodarki światowej znacznie ograniczają interesy światowych korporacji czy rządów poszczególnych krajów. Korporacje światowe, dążąc do obniżania kosztów wytwarzania, poszukują najkorzystniejszych miejsc lokalizacji (np. o najniższych kosztach płac ${ }^{1}$, tanich surowcach, bardziej liberalnych przepisach dotyczących ochrony środowiska przyrodniczego), które występują z reguły w krajach o niższym poziomie rozwoju. Prowadzi to do relatywnego ograniczania wzrostu dochodów ludności związanej z miejscem lokalizacji działalności gospodarczej, a w konsekwencji zmniejszania chłonności miejscowego rynku na nowe produkty, a także ograniczania możliwości podnoszenie poziomu i jakości życia. Wpływa to na dalsze nasilanie zróżnicowań przestrzeni w skali regionalnej, krajowej, kontynentalnej czy światowej.

Obiektywne reguły rozwoju ekonomicznego realizują się w zróżnicowanej przestrzeni układów światowych, krajowych, czy regionalnych. W zależności od poziomu rozwoju gospodarczego, społecznego i kulturowego dają one często odmienne rezultaty. Podkreśla to G. Kołodko (2008: 15): „...naukowcy zapożyczają interpretacje, elementy teorii, a nawet całe szkoły myślenia z obszarów wyżej cywilizacyjnie zaawansowanych, o odmiennych kulturach, wyższych technologiach i dojrzałych instytucjach, nie potrafiąc wszakże dostosować ich do miejscowych warunków [...] tego typu błąd w ekonomii jest współcześnie dość powszechny. W szczególności rozpanoszył się ostatnimi latami pod wpływem dominacji jednego nurtu myślenia, neoliberalizmu, który najsilniejsze grupy interesów powiązane z wielkim ponadnarodowym kapitałem dość skutecznie narzucały innym”. Podkreślają to także rozważania poświęcone m.in. zachowaniu polskich przedsiębiorstw wobec wdrażania standardów europejskich (Kuciński, 2003; Kuciński, 2004).

Można przyjąć, że kryzys finansowy, który przekształcił się w kryzys gospodarczy, w znacznym stopniu jest wynikiem konfliktów między regułami mikroekonomicznymi wykorzystywanymi przez światowe podmioty gospodarcze (banki, korporacje i inne podmioty gospodarcze) a regułami makro-, mega- i ekonomią światową, którymi rządzą się gospodarki różnej skali układów przestrzennych (Kleer, 2013; Zioło, 2003b; Zioło, 2013 )².

${ }_{1}$ Np. w 2012 roku średnie koszty 1 godziny pracy wahały się od 4,4 w Rumunii, 7,4 w Polsce i 10,6 w Czechach do 50,4 w Niemczech, 32 w Holandii i 346 euro w Luksemburgu (Baj, 2013).

2 Przykładem tego mogą być zachowania wielu światowych korporacji, które w celu uniknięcia płacenia podatków w kraju macierzystym przenoszą swoje siedziby do tzw. rajów podatkowych. Zjawisko to szczególnie mocno nasila się w sytuacji rosnącego fiskalizmu rządu. 


\section{STRUKTURA PRZESTRZENNA PRZEMYSLU}

Kryzys gospodarczy obejmuje wszystkie dziedziny życia gospodarczego, społecznego i kulturowego. W szczególnie silnym stopniu zaznacza się w sektorze bankowym i działalności różnorodnych podmiotów gospodarczych (przemysłowych, usługowych). Wpływa także na zmiany potencjału i struktury przestrzennej przemysłu w różnych skalach układów przestrzennych. Aby poznać to zjawisko, ważną rolę odgrywa coraz precyzyjniejsze poznawanie i wyjaśnianie funkcjonowania struktury przestrzennej przemysłu jako jednej z obiektywnych przestrzeni geograficznych (Zioło, 2003a). Przyjmujemy, że struktura przestrzenna przemysłu obejmuje różnorodne przedsiębiorstwa i zakłady przemysłowe oraz zachodzące między nimi relacje aktywne i pasywne (Zioło, 1997). Na gruncie nauk ekonomicznych Secomski (1956) i Florecie (1965), podając przykłady różnego rodzaju struktur przemysłowych, przyjmują, że podstawowymi elementami struktury przestrzennej przemysłu są zakłady przemysłowe oraz ogół stosunków zachodzących między nimi, które określają wzajemne więzi produkcyjne, ekonomiczne i społeczne.

Pojęcie „struktura przestrzenna przemysłu” do krajowej literatury geograficznej wprowadził Dziewoński (1946; Fajferek, 1966), przy podejmowaniu problematyki kształtowania zespołu produkcyjnego w teorii lokalizacji i praktyce planowania gospodarczego. Kukliński (1954), zastanawiając się nad tym pojęciem, stwierdził, że jest ono nadrzędne w stosunku do pojęć „rozmieszczenie przemysłu” i „lokalizacja przemysłu”. W niniejszych rozważaniach przyjmujemy, że struktura przestrzenna przemysłu jest jedną z obiektywnych przestrzeni społeczno-gospodarczych, charakteryzującą się zbiorem przedsiębiorstw (zakładów) przemysłowych, przemysłowo-usługowych i usługowych. Odznaczają się one różnym potencjałem ekonomicznym, jakością produkcji i usług, przynależnością do określonych branż oraz spełnianiem określonych funkcji gospodarczych i społecznych (Zioło, 1970; Zioło, 1973a). Relacje zachodzące między nimi kształtują się w wyniku natężenia sił techniczno-ekonomicznych, które umożliwiają powiązania przestrzenno-produkcyjne (Fajferek, 1966; Misztal, 1962; Misztal, 1970; Pakuła 1965; Pakuła, 1973b), kapitałowo-finansowe i instytucjonalne oraz organizacyjne, występujące na terenie różnej skali układów przestrzennych (Fajferek, 1966; Zioło, 1973). W konsekwencji struktura przestrzenna przemysłu charakteryzuje się różną atrakcyjnością dla lokalizacji i skupiania przedsiębiorstw, których występowanie kształtuje różne formy przestrzennej koncentracji przemysłu: zespoły, ośrodki, okręgi, kompleksy, klastry (Zioło, 1970).

\section{MIERNIKI POTENCJAEU EKONOMICZNEGO PRZEDSIĘBIORSTW}

Przedsiębiorstwa przemysłowe, jak już wspomniano, nie są jednorodnymi elementami, ale odznaczają się bardzo dużym zróżnicowaniem w zakresie potencjału ekonomicznego, przynależności do różnych branż, spełniania określonych funkcji w procesie produkcyjnym, w strukturze przestrzennej przemysłu, a także w przestrzeni geograficznej. Zróżnicowanie 
przedsiębiorstw przemysłowych w zakresie potencjału techniczno-ekonomicznego ilustrują (Zioło, 1972; Zioło, 1973b):

- potencjał produkcyjny, produkcyjno-usługowy i usługowy mierzony wielkością produkcji w jednostkach fizycznych oraz w jednostkach wartościowych: wartością produkcji, sprzedaży, aktywów, wartością rynkową, wartością przeniesioną, wartością nakładów inwestycyjnych, wartością środków trwałych i in.,

- potencjał techniczny pokazuje: moc zainstalowanych urządzeń wytwórczych i odbiorczych, zużycie energii (elektrycznej, gazowej, cieplnej), powierzchnię produkcyjną, powierzchnię zakładu, powierzchnię działki będącą do dyspozycji przedsiębiorstwa, liczbę maszyn i urządzeń oraz poziom nowoczesności parku technicznego,

- efektywność wykorzystania potencjału produkcyjno-usługowego określa: wydajność pracy, kapitałochłonność i energochłonność produkcji, uzbrojenie pracy i in.,

- rozmiary rynku pracy stwarzanego przez przedsiębiorstwa przedstawia: liczba zatrudnionych, liczba pracujących, ich struktury demograficzne i społeczno-zawodowe, a także udział pracowników miejscowych i zasięg dojeżdżających do pracy.

Potencjał ekonomiczny i techniczny przedsiębiorstw można więc wyrazić przy pomocy wielu zmiennych, które są istotne w zakresie realizacji założonego przedmiotu i celu badawczego. Analizując przedsiębiorstwa przemysłowe od strony działalności produkcyjnej, ważną rolę ogrywają np. wartość produkcji sprzedanej czy zysku, badając go od strony rynku pracy, ważnym miernikiem jest liczba pracujących lub zatrudnionych, od strony osadniczej ważnym miernikiem jest powierzchnia zajmowana przez przedsiębiorstwo, natomiast od strony jego funkcji w przestrzeni istotny jest zasięg i nasilenie jego powiązań aktywnych i pasywnych itp. (Zioło, 1973a).

W ocenie przedsiębiorstwa szczególnie ważną rolę odgrywają dane określające efektywność wykorzystania majątku i zasobów pracy, które w znacznym stopniu wpływają na koszty produkcji, konkurencyjność oferowanych produktów, a w konsekwencji na wynik finansowy działalności przedsiębiorstwa. Analizując przedsiębiorstwa w świetle wartości tych cech (mierników), możemy otrzymać różny obraz struktury branżowej i przestrzennej przemysłu. Dlatego dla określenia potencjału przemysłowego często przyjmowana jest wartość miernika syntetycznego, który pozwala nie tylko na określenie potencjału przedsiębiorstwa, ale także na wskazanie, który z mierników empirycznych i w jakim stopniu wpływa na wartość miernika syntetycznego (Zioło, 1972; Zioło, 1973b).

Przedsiębiorstwa przemysłowe $\mathrm{w}$ zależności od profilu produkcji reprezentują różne działy przemysłu (branże), które ustalane są w oparciu o przyjęte zasady klasyfikacji gospodarki narodowej, w tym działalności przemysłowej. Często wprowadzane zmiany klasyfikacji gospodarki narodowej utrudniają analizę zmian strukturalnych przemysłu i gospodarki narodowej w dłuższym okresie, stąd niezbędne są pewne szacunki dające w miarę porównywalny obraz dokonujących się zmian.

W przedsiębiorstwach wielozakładowych poszczególne jednostki mogą reprezentować różne działy i spełniać różne funkcje w procesie produkcji wyrobów finalnych. Mogą one wykonywać całość wyrobów finalnych lub tylko wybrane jego elementy, np. przygotowanie surowców, dostarczanie energii, wykonywanie podzespołów w ramach powiązań kooperacyjnych, 
dokonywanie montażu podzespołów dostarczanych z innych zakładów, zapewniające obrót finansowy, a także zajmujące się marketingiem i sprzedażą. Skupienie w przedsiębiorstwie wielu oddziałów spełniających różne funkcje wynika z rachunku ekonomicznego. Dlatego przedsiębiorstwa często zlecają wykonywanie części tych zadań firmom zewnętrznym, co jest dla nich bardziej korzystne, aniżeli utrzymywanie ich w strukturze przedsiębiorstwa.

\section{FUNKCJE PRZEDSIĘBIORSTW PRZEMYSŁOWYCH}

\section{W STRUKTURZE PRZESTRZENNEJ PRZEMYSŁU}

W badaniach geograficznych szczególnie istotne jest określenie funkcji przedsiębiorstw oraz ich znaczenia w strukturze przestrzennej przemysłu. Ważną rolę w tym zakresie odgrywa wielkość potencjału techniczno-ekonomicznego oraz zasięg oddziaływania przestrzennego $\mathrm{w}$ aspekcie powiązań techniczno-ekonomicznych i powiązań rynkowych, ponieważ $\mathrm{w}$ istotnym stopniu wpływają one na rozmiary istniejącej bazy techniczno-ekonomicznej oraz na jej możliwości rozwojowe (Zioło, 1973b).

Biorąc pod uwagę znaczenie przedsiębiorstwa w przestrzeni społeczno-gospodarczej, można wyróżnić przedsiębiorstwa o funkcjach: lokalnych, standardowych (regionalnych), krajowych, międzynarodowych i światowych.

Przedsiębiorstwa o funkcjach lokalnych pracują głównie na potrzeby określonej jednostki osadniczej (wsi, gminy, np. piekarnie, rozlewnie wód, remonty pojazdów mechanicznych). Zasięg ich oddziaływania ogranicza się do stosunkowo niewielkiego obszaru, a rozmiary ich produkcji i usług nawiązują do chłonności rynku lokalnego. Mogą je reprezentować pojedyncze zakłady, które mają monopol na określoną działalność na tym niewielkim rynku, lub zakłady spełniające identyczne funkcje. Wielość zakładów o tych samych funkcjach uruchamia z reguły relacje konkurencyjne bądź współpracy na zasadzie umów dżentelmeńskich przedsiębiorców, którzy dokonują między sobą podziału lokalnego rynku. W ten sposób ograniczają oni mechanizmy konkurencji oraz oszczędzają środki przeznaczane na ten cel. Przedsiębiorstwa tego typu reprezentują zakłady o stosunkowo niewielkim potencjale technicznym i ekonomicznym, w większości są to firmy rodzinne, które tworzą rynek pracy dla stosunkowo niewielkiej liczby pracowników. Powszechnie występują one w strukturze przestrzennej przemysłu i odznaczają się w miarę równomiernym rozmieszczeniem. Nawiązują do potencjału demograficznego i poziomu rozwoju danej jednostki przestrzennej, które wyznacza im określony rozmiar rynku. Natomiast w zakresie powiązań surowcowych i zaopatrzenia mogą mieć znacznie szerszy zasięg oddziaływania (regionalny), a w zakresie powiązań technicznych związanych z zaopatrzeniem w maszyny i urządzenia oraz części zamienne mogą mieć zasięg krajowy, a nawet międzynarodowy. Lokalizacja i rozmiary działalności tej kategorii zakładów nawiązują jednak głównie do pojemności rynku lokalnego.

Podobnie kształtują się przedsiębiorstwa o funkcjach ponadlokalnych. Zasięg ich oddziaływania jest większy i obejmuje obszar kilku gmin, powiatu lub kilku powiatów. Charakter ich działalności sprawia, że układ lokalny stanowi dla nich zbyt mały rynek 
i muszą zabiegać o rynki na większym obszarze. Wśród nich, obok lokalizacji rynkowej, występują także zakłady o lokalizacji wiązanej, np. związane z występowaniem i eksploatacją surowców mineralnych (glina ceramiczna, piaskownia, kamieniołom). Ich rynek tworzy nie tylko ludność, ale także przedsiębiorstwa, z którymi współpracują, np. w zakresie dostaw materiałów i surowców lub podzespołów w ramach powiązań kooperacyjnych.

Zakłady o funkcjach regionalnych swoją działalnością obejmują rynek województwa, a często także rynki województw sąsiednich. $Z$ reguły odznaczają się one większym potencjałem techniczno-ekonomicznym, wymagają specjalistycznych urządzeń oraz usług budowlano-montażowych czy remontowych. Rynek regionalny może stwarzać różne zapotrzebowanie na oferowane produkty, od produktów bardzo pospolitych po produkty unikalne. Firmy te charakteryzują się większym stopniem koncentracji przestrzennej, stąd zlokalizowane są z reguły w większych miastach. Wśród nich występują także przedsiębiorstwa o lokalizacji wiązanej i wymagające specjalnych miejsc ze względu na charakter prowadzonej działalności (np. występowanie surowców mineralnych, zasobów leśnych).

Zakłady o funkcjach komplementarnych związane są bardzo ściśle z przedsiębiorstwami o funkcjach krajowych, międzynarodowych i światowych, dla których wykonują prace usługowe, remontowe, a także dostarczają im określonych produktów w ramach powiązań kooperacyjnych $\mathrm{i}$ in.

Funkcje krajowe reprezentują przedsiębiorstwa pracujące na potrzeby rynku krajowego. W strukturze przestrzennej odznaczają się one sporadycznym występowaniem, głównie w większych miastach lub w bezpośrednim sąsiedztwie występowania surowców (mineralnych, rolniczych), a rozmiary ich potencjału techniczno-ekonomicznego nawiązują do chłonności rynku krajowego.

Funkcje międzynarodowe pełnią zazwyczaj korporacje pracujące na potrzeby rynku kilku krajów, natomiast funkcje światowe reprezentują korporacje obejmujące swoim zasięgiem przestrzeń globalną. Odznaczają się one bardzo złożoną strukturą wewnętrzną, którą steruje zarząd zlokalizowany w przeważającym stopniu na terenie krajów o wysokim poziomie rozwoju (Boguś, 2011; Bonar, 2011; Kilar, 2009a; Kilar, 2009b; Kilar, 2010; Kilar, 2011; Wajda, 2003; Wajda, 2006; Wajda, Zalewska, 2003; Wajda, Zoričič-Wołek, 2003; Zioło, 2001; Zioło, 2003b; Zioło, 2006; Zioło, 2011). Przedsiębiorstwa tego typu charakteryzują się dużym potencjałem ekonomicznym oraz odgrywają znaczącą rolę w gospodarce światowej (Zioło, 2003c). Prowadzą działalność produkcyjną lub usługową w oddziałach zlokalizowanych na terenie większości krajów świata, dostosowaną do potrzeb określonego rynku³. Korporacje te wytwarzają $\mathrm{w}$ światowej przestrzeni gospodarczej różnego typu powiązania w zakresie: zaopatrzenia surowcowego, wytwarzania określonych półfabrykatów, podzespołów lub montażu gotowych produktów, a także w zakresie energii i in. Mogą także wpływać na aktywizację gospodarczą innych krajów m.in. poprzez bezpośrednie inwestycje zagraniczne, z wykorzystaniem ułatwień stwarzanych np. w specjalnych strefach ekonomicznych (Domański, 2001). Ten typ reprezentują także przedsiębiorstwa, których lokalizacja wynika

${ }^{3}$ W 2003 roku korporacja Nokia miała 116 oddziałów zlokalizowanych na terenie 53 krajów, w tym najwięcej na terenie Stanów Zjednoczonych (17) oraz w Brazylii, Wielkiej Brytanii i Chinach (po 7) i Indiach (3), a MBI mała oddziały zlokalizowane na terenie 130 krajów (Wajda, 2006; Wajda, Zoričič-Wołek, 2003). 
z konieczności dostępu do unikalnych w przestrzeni światowej zasobów surowcowych, jak np. metale ziem rzadkich ${ }^{4}$, rudy metali kolorowych, które są niezbędne do produkcji nowoczesnych produktów. Mogą występować tu także firmy wytwarzające produkty codziennego użytku po relatywnie niskich kosztach, np. produkty oferowane przez firmy azjatyckie.

Zasięg i chłonność obszarów rynkowych poszczególnych typów przedsiębiorstw może ulegać zmianie. Wynika to ze zwiększania lub zmniejszania zasobów finansowych ludności $\mathrm{i}$ instytucji, z decyzji wynikających z polityki społeczno-ekonomicznej państwa lub z innych potrzeb wynikających z konieczności zamówień publicznych (np. cele obronne, wdrażanie nowych metod zarządzania czy pobudzanie innowacyjności gospodarki), a także z jakości stosunków politycznych między poszczególnymi krajami. Przedsiębiorstwa te dokonują także ekspansji przestrzennej w zakresie poszukiwania nowych rynków, czemu w głównym stopniu sprzyja ich konkurencyjność w zakresie cen i jakości oferowanych produktów.

W konsekwencji poszczególne typy przedsiębiorstw dostosowują rozmiary swojej działalności produkcyjnej i usługowej do chłonności obszarów rynkowych, a ich głównym celem jest osiąganie maksymalnych korzyści ekonomicznych obecnie lub w przewidywanej przyszłości.

Przedstawione typy przedsiębiorstw przemysłowych w przestrzeni gospodarczej nie są elementami odizolowanymi, ale zachodzą między nimi określone relacje przestrzenne (tab. 2).

Generalnie można wyróżnić trzy rodzaje relacji.

Pierwszy rodzaj reprezentują relacje zachodzące między tymi samymi typami przedsiębiorstw: lokalnymi $\left[\mathrm{x}_{11}^{\mathrm{x}}\right]$, regionalnymi $\left[\mathrm{x}_{22}^{\mathrm{x}}\right]$, komplementarnymi $\left[\mathrm{x}_{33}^{\mathrm{x}}\right]$, krajowymi $\left[\mathrm{x}_{44}^{\mathrm{x}}\right]$, międzynarodowymi $\left[\mathrm{x}_{55}^{\mathrm{x}}\right]$, światowymi $\left[\mathrm{x}_{66}^{\mathrm{x}}{ }_{66}\right]$.

Drugi typ to relacje aktywne, które przedstawiają wiersze tabeli. Ilustrują one oddziaływanie danego typu przedsiębiorstwa na pozostałe typy przedsiębiorstw, np. wpływ przedsiębiorstw lokalnych: na regionalne ilustruje relacja $\left[\mathrm{x}_{12}\right]$, na komplementarne $-\left[\mathrm{x}_{13}^{\mathrm{x}}\right]$, na krajowe $-\left[\mathrm{x}_{14}^{\mathrm{x}}\right]$, na międzynarodowe $\left[\mathrm{x}^{\mathrm{x}}{ }_{15}\right]$, a na światowe $-\left[\mathrm{x}_{16}^{\mathrm{x}}\right]$. Podobnie wpływ przedsiębiorstw krajowych na regionalne przedstawia $\left[\mathrm{x}_{42}^{\mathrm{x}}\right]$, na międzynarodowe - $\left[\mathrm{x}_{45}^{\mathrm{x}}\right]$, a wpływ przedsiębiorstw światowych na: lokalne przedstawia $\left[\mathrm{x}_{61}^{\mathrm{x}}\right]$, regionalne $-\left[\mathrm{x}_{62}^{\mathrm{x}}\right]$, krajowe $-\left[\mathrm{x}_{64}^{\mathrm{x}}\right]$ itp.

Trzeci typ obejmuje relacje pasywne, które przedstawiają kolumny tabeli. Ilustrują one oddziaływanie poszczególnych typów przedsiębiorstw na dany typ. Np. oddziaływanie na przedsiębiorstwa krajowe przedstawiają relacje od $\left[\mathrm{x}^{\mathrm{x}}{ }_{14}\right]$ do $\left[\mathrm{x}_{64}^{\mathrm{x}}\right]$, a na przedsiębiorstwa światowe - relacje od $\left[\mathrm{x}^{\mathrm{x}}{ }_{16}\right]$ do $\left[\mathrm{x}_{65}^{\mathrm{x}}\right]$.

Wartości $\left[\mathrm{x}_{54}^{\mathrm{x}}\right] \mathrm{i}\left[\mathrm{x}^{\mathrm{x}}{ }_{45}\right]$ nie są sobie równe - pierwsza $\mathrm{z}$ nich przedstawia wpływ przedsiębiorstw międzynarodowych na przedsiębiorstwa krajowe, a druga relacje odwrotne, wpływ przedsiębiorstw krajowych na przedsiębiorstwa międzynarodowe. Relacje te można odnosić do pojedynczych przedsiębiorstw lub grupy przedsiębiorstw reprezentujących ten sam typ.

${ }^{4}$ Metale ziem rzadkich obejmują 17 pierwiastków (m.in.: terb, lantan, neodym, lutet, cer) i mają szerokie zastosowanie w przemyśle zaawansowanych technologii (m.in.: produkcja katalizatorów, silników do pojazdów elektrycznych, ekranów płaskich, dysków twardych, obiektywów kamer, sprzętu medycznego). Do tej pory ok. 97\% ich dostaw na światowy rynek pochodzi z Chin. 


\begin{tabular}{|c|c|c|c|c|c|c|c|c|c|c|c|c|c|}
\hline$\square^{m}$ & $z_{x}^{m}$ & $=x^{3}$ & $=x^{\infty}$ & $F^{2}$ & $=x^{n}$ & $=x^{8}$ & $\bar{x}^{2}$ & $3^{2}$ & $\sum_{i}^{\infty}$ & $\bar{x}^{\text {? }}$ & $z^{2}$ & $z^{2}$ & $z^{\infty}$ \\
\hline$D^{2}$ & $=\simeq$ & $=2$ & $={ }^{\infty}$ & $=\mathcal{F}^{7}$ & $\equiv$ & $=\tilde{x}^{\delta}$ & $\stackrel{2}{2}$ & $\sum^{2}$ & $\dot{\lambda}^{\infty}$ & $\overline{7}^{7}$ & $z^{2}$ & $=\pi$ & $\equiv$ \\
\hline$b^{-}$ & $=$ & $=\bar{x}$ & $=\bar{x}$ & $\bar{x}^{7}$ & $\bar{x} \bar{x}$ & $\bar{x}^{\overline{6}}$ & $\bar{\lambda}$ & $\vec{\lambda}^{2}$ & $\bar{x}$ & $\bar{\lambda}^{7}$ & $z^{\prime}$ & $\Xi_{\bar{N}}^{\bar{N}}$ & $z^{m}$ \\
\hline$\lambda^{+}$ & $x_{x}^{ \pm}$ & 齐 & $x_{x}^{ \pm}$ & $\mathrm{x}^{j}$ & 䓌 & $x_{x}^{t}$ & $\mathrm{\lambda}^{ \pm}$ & $\lambda_{\lambda}^{ \pm}$ & 志 & $\mathrm{i}^{+}$ & $\partial^{ \pm}$ & $\mathrm{\partial}^{\text {से }}$ & 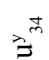 \\
\hline$\lambda^{m}$ & $x^{m}$ & $x^{\pi}$ & $x^{n}$ & $\mathrm{x}^{\mathrm{q}}$ & $x^{i n}$ & $x^{B}$ & $\lambda^{2}$ & $\lambda^{2}$ & $\lambda^{m}$ & $\lambda^{8}$ & $z^{2}$ & $3^{2}$ & $\mathrm{z}^{m}$ \\
\hline$\nu^{2}$ & 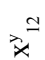 & $x^{2}$ & $x^{\infty}$ & $x^{7}$ & $x^{n}$ & $x_{x}^{\sigma}$ & $2^{2}$ & $\lambda^{2}$ & $\lambda^{\infty}$ & $3^{7}$ & $\therefore$ & $3^{2}$ & $\mathrm{z}^{m}$ \\
\hline$\lambda^{-}$ & 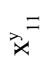 & $\lambda_{\bar{x}}^{\bar{N}}$ & $\overrightarrow{\bar{m}}$ & $i^{F}$ & $\lambda_{\bar{x}}^{\bar{n}}$ & $x_{x}^{\overline{0}}$ & ${ }_{\lambda}=$ & $\lambda_{\lambda}^{\bar{N}}$ & $\bar{\lambda}$ & $\lambda^{7}$ & $\Rightarrow=$ & $\vec{\partial}^{\bar{N}}$ & $\mathrm{z}^{\bar{m}}$ \\
\hline$x^{6}$ & $\underset{x}{x}$ & 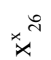 & $x_{x}^{\infty}$ & $x_{x}^{+}$ & $x_{x}^{\circ}$ & $x_{x}^{8}$ & ${ }_{x}^{x}$ & $x_{i}^{\circ}$ & $x_{\lambda}^{\infty}$ & $x_{3}^{f}$ & $\stackrel{0}{=}$ & $\stackrel{x=}{=}$ & $\stackrel{\infty}{\equiv}$ \\
\hline$x^{m}$ & $x_{x}^{n}$ & $x_{x}^{27}$ & $\underset{x}{x}$ & $x_{x}^{i f}$ & $x_{x}^{i n}$ & $x_{x}^{n}$ & $x^{2}$ & $x^{2 n}$ & $x_{\lambda}^{\infty}$ & $x^{i f}$ & $x^{2}$ & $\stackrel{0}{=}$ & $\stackrel{m}{\Rightarrow}$ \\
\hline$x^{+}$ & $x_{x}^{ \pm}$ & $x_{x}^{ \pm}$ & $x_{x}^{ \pm}$ & $x_{x}^{+}$ & $x_{x}^{*}$ & $x_{x}^{ \pm}$ & $x^{ \pm}$ & $x_{i}^{ \pm}$ & 莣 & $x_{i}^{+}$ & $\stackrel{ \pm}{ \pm}$ & $\ddot{n}=$ & $\stackrel{ \pm}{J}$ \\
\hline$x^{m}$ & $x_{x}^{m}$ & $x_{x}^{\pi}$ & $x_{x}^{m}$ & $x_{x}^{g}$ & $x_{x}^{n}$ & $x_{x}^{B}$ & $x^{2}$ & $x^{n}$ & $x_{\lambda}^{\infty}$ & $x_{>}^{g}$ & $x_{=}^{9}$ & $\stackrel{x}{*}$ & $\stackrel{m}{\Rightarrow}$ \\
\hline$x^{2}$ & $x_{x}^{9}$ & $x_{x}^{2}$ & $x_{x}^{\infty}$ & $x_{x}^{7}$ & $x_{x}^{n}$ & $x_{x}^{\sigma}$ & $x^{2}$ & $x^{2}$ & $x^{\infty}$ & $x^{7}$ & $x^{2}$ & $x_{3}^{m}$ & $\underset{\Xi}{\underbrace{\infty}}$ \\
\hline$\vec{x}$ & $x_{x}^{\prime}=$ & $x_{x}^{\bar{N}}$ & $x_{x}^{\bar{m}}$ & $x_{x}^{\exists}$ & $x_{x}^{\bar{n}}$ & $x_{x}^{\bar{b}}$ & $x^{x}=$ & ${ }_{\lambda}^{\vec{N}}$ & $x^{\bar{m}}$ & $x^{\bar{f}}$ & $x=$ & $\stackrel{x^{\bar{N}}}{ }$ & $x_{\exists}^{\bar{m}}$ \\
\hline \multirow{4}{*}{ 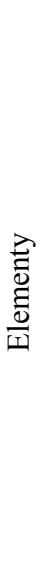 } & $x^{-}$ & $x^{N}$ & $x^{m}$ & $x^{+}$ & $x^{n}$ & $x^{0}$ & $\lambda^{-}$ & $\lambda^{2}$ & $\lambda^{m}$ & $\nu^{+}$ & $\square^{-}$ & $\rho^{2}$ & $b^{m}$ \\
\hline & & & 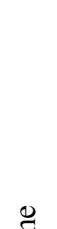 & 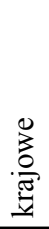 & 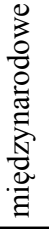 & 莕 & \multirow{2}{*}{ 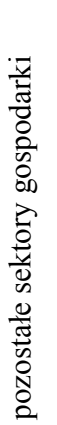 } & \multirow{2}{*}{ 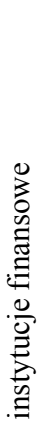 } & \multirow{2}{*}{ 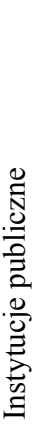 } & & \multirow{2}{*}{ 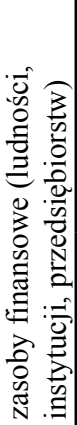 } & \multirow{2}{*}{ 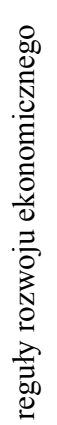 } & \multirow{2}{*}{ 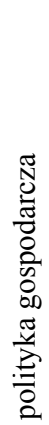 } \\
\hline & 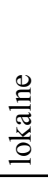 & 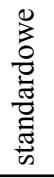 & $\begin{array}{l}\frac{\pi}{0} \\
\frac{0}{0} \\
\frac{0}{0} \\
\stackrel{0}{0} \\
\underline{0}\end{array}$ & \multicolumn{3}{|c|}{ 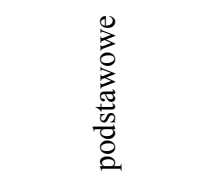 } & & & & $\begin{array}{l}\text { 总 } \\
\text { 竞 }\end{array}$ & & & \\
\hline & \multicolumn{6}{|c|}{ 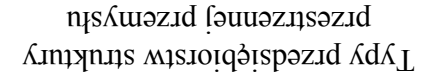 } & \multicolumn{4}{|c|}{ әเฺวZวоџО } & \multicolumn{3}{|c|}{ вциемоучильем $\bigcap$} \\
\hline
\end{tabular}


Przedstawione relacje mogą prowadzić do nasilania powiązań i korzystnie oddziaływać na zwiększanie potencjału i działalności gospodarczej danego przedsiębiorstwa, utrzymywać stałe nasilenie istniejących powiązań - wówczas wpływa to na stagnację działalności danego przedsiębiorstwa, albo mogą prowadzić do osłabiania dotychczasowych powiązań, np. w okresie kryzysu, co prowadzi do recesji ich dotychczasowej działalności, a nawet upadku. Dlatego poznanie zmieniających się relacji stwarza ważne przesłanki podejmowania strategicznych decyzji w zakresie prowadzenia działalności gospodarczej przedsiębiorstwa, zwłaszcza w okresie kryzysu gospodarczego.

W strukturze przestrzennej przemysłu wyróżnione typy przedsiębiorstw wykazują różne tendencje do koncentracji przestrzennej, w wyniku czego wykształcają się coraz większe formy - od przemysłu rozproszonego, poprzez ośrodki, okręgi, do kompleksów przemysłowych i klastrów.

\section{FUNKCJONOWANIE PRZEDSIĘBIORSTWA W OTOCZENIU}

Ważną rolę w kształtowaniu struktury przestrzennej przemysłu odgrywa otoczenie reprezentowane przez: pozostałe sektory gospodarki narodowej, instytucje finansowe, instytucje publiczne i otoczenie rynkowe. Elementy otoczenia, podobnie jak przedsiębiorstwa, nie funkcjonują samodzielnie, ale także wykształcają się między nimi różnorakie relacje, które opisują macierze od $\left[\mathrm{y}^{\mathrm{y}}{ }_{11}\right]$ po $\left[\mathrm{y}_{44}^{\mathrm{y}}\right]$. Poszczególne elementy otoczenia w odmiennym stopniu wpływają na poszczególne rodzaje przedsiębiorstw przemysłowych. Podstawowe znaczenie odgrywa otoczenie rynkowe, które stwarza określone zapotrzebowanie na produkty i usługi oferowane przez poszczególne rodzaje przedsiębiorstw, instytucje publiczne kreujące odpowiednie instrumenty pośredniego i bezpośredniego oddziaływania, które w sposób pozytywny lub negatywny mogą wpływać na rozwój działalności przedsiębiorstw. Również instytucje finansowe w określonym stopniu mogą oddziaływać na gospodarkę finansową przedsiębiorstw, oferując np. odpowiednio korzystne lub mniej korzystne możliwości finansowania ich działalności, zwłaszcza w okresie kryzysu.

Przedsiębiorstwa wraz z ich otoczeniem funkcjonują w określonych uwarunkowaniach, które opisują relacje od $\left[\mathrm{u}_{11}^{\mathrm{u}}\right]$ po $\left[\mathrm{u}_{33}^{\mathrm{u}}\right]$. Reprezentują je zasoby finansowe ludności, przedsiębiorstw i instytucji, wdrażane reguły rozwoju ekonomicznego oraz polityka gospodarcza. Uwarunkowania te również w często odmiennym stopniu mogą wpływać na działalność poszczególnych typów przedsiębiorstw. Zasoby finansowe gospodarstw domowych, instytucji i przedsiębiorstw stwarzają potencjalne rozmiary rynku, instytucje finansowe mogą oferować korzystne lub mniej korzystne warunki dla kształtowania gospodarki finansowej, np. warunki kredytowania działalności produkcyjnej. Również reguły rozwoju ekonomicznego mogą tworzyć bardziej lub mniej harmonijne reguły rozwoju, podobnie polityka gospodarcza, społeczna i kulturowa może dawać różne możliwości w zakresie samodzielności funkcjonowania podmiotów gospodarczych. Mogą się one wahać od stosowania reguł gospodarki centralnie sterowanej, poprzez gospodarkę rynkową, po gospodarkę wolnorynkową. 
W procesie kształtowania działalności gospodarczej między wyróżnionymi grupami elementów reprezentowanymi przez określone typy przedsiębiorstw, różnymi kategoriami otoczenia i różnorodnymi uwarunkowaniami zachodzą określone relacje aktywne i pasywne.

Oddziaływanie struktury przestrzennej przemysłu na otoczenie opisują macierze od $\left[\mathrm{x}_{11}^{\mathrm{y}}\right]$ do $\left[\mathrm{x}_{64}^{\mathrm{y}}\right]$, a na uwarunkowania - macierze od $\left[\mathrm{x}_{11}^{\mathrm{u}}\right]$ do $\left[\mathrm{x}_{63}^{\mathrm{u}}\right]$.

Oddziaływanie otoczenia na strukturę przestrzenną przemysłu opisują macierze od $\left[\mathrm{y}_{11}^{\mathrm{x}}\right]$ do $\left[\mathrm{y}^{\mathrm{x}}{ }_{46}\right]$, a na uwarunkowania - macierze od $\left[\mathrm{y}_{11}^{\mathrm{u}}\right]$ do $\left[\mathrm{y}_{43}^{\mathrm{u}}\right]$.

Oddziaływanie uwarunkowań na różne typy przedsiębiorstw określają macierze od $\left[\mathrm{u}^{\mathrm{x}}{ }_{11}\right]$ do $\left[\mathrm{u}^{\mathrm{x}}{ }_{36}\right]$, a na otoczenie - macierze od $\left[\mathrm{u}^{\mathrm{y}}{ }_{11}\right]$ do $\left[\mathrm{u}^{\mathrm{y}}{ }_{34}\right]$.

Podobnie w kolumnach mamy przedstawione relacje pasywne odnoszące się do wyróżnionych grup elementów.

W świetle przedstawionych rozważań należy przyjąć, że funkcjonowanie przedsiębiorstw dokonuje się w wyniku bardzo złożonych relacji zachodzących nie tylko między różnymi przedsiębiorstwami i ich typami, ale także między określonymi kategoriami otoczenia oraz uwarunkowaniami.

Zmiana potencjału i nasilenia powiązań jednego z elementów uaktywnia łańcuch zmian przyczynowo-skutkowych dezorganizujący cały system i stwarza sytuacje kryzysowe. Dlatego w celu zapobiegania niekorzystnym zjawiskom duże znaczenie ma poznanie negatywnych przyczyn zakłócających dotychczasowy proces funkcjonowania danej całości. Natomiast doraźne działania, nieuwzględniające wszystkich relacji, mogą pogłębić sytuację kryzysową lub przenieść jej negatywne skutki na dalsze lata. Funkcjonowanie przedstawionego systemu przemysłowego zakłóca także wprowadzanie na rynek nowych konkurencyjnych produktów. Wypierają one dotychczasowe produkty, przyczyniając się do recesji czy zanikania przedsiębiorstw ${ }^{5}$.

\section{ZACHOWANIE PRZEDSIĘBIORSTWA PODCZAS KRYZYSU GOSPODARCZEGO}

Kryzys gospodarczy stwarza niekorzystne uwarunkowania dla działalności gospodarczej, funkcjonowania instytucji i gospodarstw domowych. W funkcjonowaniu przedsiębiorstw wpływa on na zakłócenie ich działalności, co przejawia się zmniejszaniem rozmiarów produkcji. W głównym stopniu wynika to z ograniczenia chłonności rynku na oferowane produkty. Z kolei pociąga to za sobą zmniejszanie zapotrzebowania na surowce, materiały, wyroby wytwarzane w ramach powiązań kooperacyjnych z innymi przedsiębiorstwami oraz zapotrzebowania na usługi. W konsekwencji zmniejszają się środki finansowe przedsiębiorstw, co stanowi poważną barierę dla kontynuowania działalności wytwórczej. W wyniku braku środków finansowych lub ich oszczędzania zmniejsza się także popyt stwarzany przez inne przedsiębiorstwa, gospodarstwa domowe i instytucje. Znaczącą rolę w tym zakresie

${ }^{5}$ Przykładem tego może być osłabienie pozycji firmy Nokia, która - mając ok. 1/3 światowego rynku - wskutek wprowadzenia nowego produktu znacznie osłabiła swoją działalność, podobnie upadek fabryki produkującej tradycyjne aparaty fotograficzne na filmy z powodu zastępowania jej produktów aparatami cyfrowymi. 
odgrywa także międzynarodowe otoczenie rynkowe, które ogranicza zapotrzebowanie na produkty, usługi czy dostawy kooperacyjne. Wynika to ze zmieniającej się sytuacji ekonomicznej zagranicznych odbiorców, zależy także od stosunków politycznych, które mogą sprzyjać eksportowi produktów lub stwarzać dla nich bariery celne, czy wprowadzać celowe embarga na dostarczane do tej pory produkty (Zioło, 2011).

Ograniczanie produkcji wpływa na zmniejszanie zasobów finansowych i kapitałowych przedsiębiorstwa, ograniczanie rynku pracy, co powoduje zmniejszanie poziomu zatrudnienia, ograniczanie powiązań zaopatrzeniowych i kooperacyjnych z innymi przedsiębiorstwami w zakresie dostaw surowcowych, materiałów, półfabrykatów, usług czy gotowych elementów oraz powiązań z innymi podmiotami gospodarczymi. Prowadzi to z kolei do ograniczenia rozmiarów produkcji dostawców, a także do ograniczenia zatrudnienia, a w przypadku nasilających się zatorów finansowych - do upadłości firm.

Podstawową rolę w tym zakresie odgrywa kondycja finansowa i kapitałowa przedsiębiorstwa. Przy ograniczaniu płynności finansowej pomóc mogą także instytucje finansowe i budżet państwa, które poprzez różne formy pomocy mogą umożliwić dalszą działalność przedsiębiorstwa. Duże znaczenie dla ożywienia rynku mają również zasoby finansowe innych przedsiębiorstw i gospodarstw domowych. W zależności od sytuacji gospodarczej zasoby te mogą wpływać na zwiększanie zapotrzebowania na określone produkty lub mogą być zachowane w formie oszczędności, które w przyszłości zostaną wykorzystane podczas ożywienia gospodarczego do wychodzenia z kryzysu. Obecnie w części gospodarstw domowych i przedsiębiorstw obserwujemy zwiększanie oszczędności finansowych, a u innych występuje znaczne ich zadłużenie i trudności ze spłatą należności finansowych (Zioło, 2013).

Na charakter tego procesu wpływa określona polityka gospodarcza państwa, a szczególnie polityka fiskalna i polityka kredytowa instytucji finansowych. W przypadku odpowiednich nadwyżek budżetowych państwo może zmniejszyć obciążenia finansowe przedsiębiorstw na rzecz budżetu i innych instytucji finansowych, ale może także zwiększyć obciążenia finansowe przedsiębiorstw, co będzie prowadziło do ograniczania ich możliwości rozwojowych w okresie wychodzenia z kryzysu i pojawienia się koniunktury gospodarczej. Nadmierne obciążenia finansowe przedsiębiorstw na rzecz budżetu prowadzić będą do ograniczania zatrudnienia nowych pracowników oraz zmniejszania możliwości aktywizacji zawodowej ludności. Wpływa to na: emigrację zarobkową, nasilanie się rozmiarów bezrobocia, pojawianie się zjawisk patologii społecznej, potrzebę środków przeznaczanych na różnego rodzaju zasiłki. To z kolei oddziałuje na dalsze zmniejszanie się dochodów budżetowych państwa i zasobów finansowych gospodarstw domowych, które ograniczają swój popyt do najbardziej niezbędnych produktów. Prowadzi to do zadłużania państwa w krajowych lub zagranicznych instytucjach finansowych.

Wyróżnione typy przedsiębiorstw przemysłowych w różnym stopniu reagują na kryzys gospodarczy. Na rozmiary działalności przedsiębiorstw o funkcjach lokalnych i ponadlokalnych podstawowy wpływ wywiera chłonność rynku o stosunkowo niewielkim obszarze, ograniczonym zazwyczaj do wsi, gminy lub kilku sąsiednich gmin. Zależy ona od zasobów finansowych ludności, które mogą pochodzić z pracy w miejscowych przedsiębiorstwach, z działalności rolniczej, z niezarobkowych źródeł utrzymania (emerytur, zasiłków, zapomóg), 
z pracy zarobkowej w otoczeniu krajowym czy międzynarodowym (migracji zarobkowej), ale także od zmian gustów konsumentów ${ }^{6}$. Szczególnie negatywny wpływ zaznacza się w zakresie działalności firm usługowych, gdyż lokalny rynek rezygnuje z ich ofert, a ich funkcje przejmowane są przez członków gospodarstwa domowego lub odkładane na przyszłe lata.

$\mathrm{Na}$ zachowania przedsiębiorstw o funkcjach regionalnych także wpływa wielkość zasobów finansowych ludności, ale również ograniczanie zapotrzebowania na bardziej wyspecjalizowane usługi czy dostawy kooperacyjne przedsiębiorstw krajowych lub zagranicznych.

Ograniczenie działalności przedsiębiorstw o funkcjach komplementarnych bezpośrednio zależy od zmian zapotrzebowania dużych przedsiębiorstw, z którymi wykazują one powiązania funkcjonalne w zakresie prac badawczo-rozwojowych, remontowych, dostaw kooperacyjnych, wytwarzania gotowych wyrobów, usług finansowych i in.

Nasilenie kryzysu w przedsiębiorstwach o funkcjach krajowych zależy od stopnia otwartości gospodarki na otoczenie światowe, zwłaszcza na przedsiębiorstwa i obszary objęte kryzysem gospodarczym. Im wyższy stopień otwarcia gospodarki na otoczenie, zwłaszcza objęte kryzysem, tym większe zaznaczają się ograniczenia działalności produkcyjno-usługowej.

Zachowanie korporacji o funkcjach międzynarodowych w głównym stopniu zależy od zmiany sytuacji rynkowej obszarów, z którymi utrzymuje ona powiązania gospodarcze. Obecnie szczególnie silnie zaznacza się to w zakresie kurczenia się rynku przemysłu samochodowego, co wpływa na ograniczanie dostaw różnych podzespołów przez krajowych dostawców dla koncernów międzynarodowych. Kryzys gospodarczy w przestrzeni światowej występuje nierównomiernie i obejmuje niekiedy tylko obszary niektórych krajów czy kontynentów lub kraje skupione w określonych organizacjach gospodarczo-politycznych. Dlatego podstawowym zadaniem przedsiębiorstw jest poszukiwanie obszarów rynkowych, które w mniejszym stopniu zostały objęte kryzysem. Działania te bardzo często wspierają także rządy poszczególnych krajów.

Przedsiębiorstwa o funkcjach światowych, obejmujące swoim oddziaływaniem przestrzeń globalną, w latach kryzysu osłabiają swoją działalność związaną głównie z obszarami kryzysu gospodarczego, natomiast częściowo rekompensują swoje straty poprzez rozwój współpracy z obszarami znajdującymi się poza oddziaływaniem kryzysu (obecnie np. z Chinami czy Indiami).

Podczas kryzysu zazwyczaj nasilają się procesy polaryzacji, różnicujące strukturę przestrzenną przemysłu. W zależności od ich pozycji na rynku oraz dokonujących się przemian techniczno-ekonomicznych i produkcyjnych przedsiębiorstwa mogą wykazywać różne tendencje zachowań: mogą być likwidowane, wykazywać tendencje do zanikania, stagnacji poprzez utrzymywanie na stałym poziomie rozmiarów produkcji, ale także mogą się rozwijać w wyniku zwiększania się zapotrzebowania rynku na ich produkty, mogą również pojawiać się nowe przedsiębiorstwa, które podejmują wytwarzanie nowych i bardziej konkurencyjnych produktów.

${ }^{6}$ Np. w latach 2008-2011 zmniejszyła się w Polsce liczba piekarń z 12,4 tys. do 11,0 tys. co związane było z ograniczeniem konsumpcji chleba na rzecz innych produktów, a także z rozwijaniem konkurencyjnej produkcji przez duże firmy handlowe. 
Podczas kryzysu poszczególne typu przedsiębiorstw mogą mieć różny dostęp do rynku i źródeł zasilania finansowego. W wyniku określonej polityki państwa mogą być dla nich stwarzane korzystne możliwości pozyskiwania kredytów, zwiększania popytu rynkowego, np. poprzez zamówienia publiczne na cele: obronne, konieczność utrzymania rynków pracy, przystosowania się wybranych typów przedsiębiorstw do nowych warunków konkurencyjnych itp.

Kształtowanie struktury przestrzennej przemysłu podczas kryzysu dokonuje się w wyniku nasilania mechanizmu konkurencji na rynku, który stwarza zmniejszone zapotrzebowanie na oferowane produkty. Mechanizm ten wpływa na sytuację finansową przedsiębiorstw i ich otoczenia. W strukturze przestrzennej dokonuje się pewna selekcja przedsiębiorstw występujących w układach przestrzennych oraz przemiana ich potencjału ekonomicznego. Proces ten może być w różnym stopniu sterowany poprzez zmianę otoczenia i warunków rozwoju działalności gospodarczej.

\section{DYNAMIKA PRZEMYSŁU KRAJOWEGO W LATACH KRYZYSU}

Zarysowana koncepcja modelowa wskazuje na bardzo złożony proces funkcjonowania przedsiębiorstw przemysłowych, zróżnicowanych pod względem funkcji, potencjału ekonomicznego i technicznego oraz ich miejsca w strukturze przestrzennej przemysłu. $\mathrm{Na}$ skutek pojawienia się kryzysu gospodarczego następuje dysharmonia przejawiająca się m.in. w: ograniczaniu rynku na oferowane produkty czy usługi, osłabianiu lub likwidowaniu dotychczasowych powiązań rynkowych, obniżaniu zasobów finansowych i możliwości zdobywania nowych źródeł kredytowania lub otrzymywania dotacji czy ulg finansowych. W zasadniczym stopniu wpływa to na ograniczanie potencjału ekonomicznego i technicznego poszczególnych przedsiębiorstw.

W okresie kryzysu gospodarczego zachowania krajowego potencjału przemysłowego charakteryzowały się różnymi tendencjami zmian wybranych cech. W latach 2005-2008 najpoważniejszym wzrostem odznaczały się nakłady inwestycyjne, które zwiększyły się do 147,6\% (tab. 3). Oznacza to, że niektóre przedsiębiorstwa wykazywały tendencję do zwiększania potencjału produkcyjnego oraz unowocześnienia parku maszynowego, pozwalającego na rozwój nowoczesnej produkcji i zwiększenie wydajności pracy.

Nakłady inwestycyjne relatywnie były jednak stosunkowo niskie i w małym stopniu wpływały na dynamikę wartości środków trwałych, do 112,6\%. Intensywniejszym wzrostem charakteryzowała się wartość sprzedaży, która wzrosła do 127,9\%. Natomiast najniższą dynamiką, do $111,5 \%$, odznacza się liczba pracujących w przemyśle.

Zróżnicowana dynamika wartości analizowanych cech wskazuje, że wzrost wartości produkcji sprzedanej był wynikiem zwiększenia nakładów inwestycyjnych. Wpłynęły one na wzrost wydajności pracy oraz ograniczenie dynamiki zatrudnienia. 
Tab. 3. Dynamika przemysłu krajowego

\begin{tabular}{|c|c|c|c|c|}
\hline Lata & $\begin{array}{c}\text { Produkcja } \\
\text { sprzedana }\end{array}$ & $\begin{array}{c}\text { Nakłady } \\
\text { inwestycyjne }\end{array}$ & $\begin{array}{c}\text { Wartość brutto } \\
\text { środków trwałych }\end{array}$ & $\begin{array}{c}\text { Pracujący w przemyśle } \\
\text { w tys. (przeciętnie w roku) }\end{array}$ \\
\hline 2005 & 100,0 & 100,0 & 100,0 & 100,0 \\
\hline 2006 & 111,6 & 113,7 & 103,6 & 103,6 \\
\hline 2007 & 123,5 & 134,7 & 107,4 & 108,5 \\
\hline 2008 & 127,9 & 147,6 & 112,6 & 111,5 \\
\hline 2009 & 122,1 & 137,9 & 117,1 & 104,1 \\
\hline 2010 & 133,1 & 133,8 & 122,0 & 102,9 \\
\hline 2011 & 143,1 & 146,2 & 129,4 & 103,6 \\
\hline 2012 & 143,9 & 146,3 & 135,2 & 102,1 \\
\hline
\end{tabular}

Źródło: GUS. Rocznik Statystyczny 2012, 2013, GUS. Rocznik statystyczny województw 2006-2012

W latach kryzysu dynamika wartości poszczególnych cech wykazywała różne tendencje. Na sytuację kryzysową najsilniej zareagowały nakłady inwestycyjne, których dynamika zmniejszyła się z 147,6 w 2008 roku do 133,8\% w 2010 roku, po czym wzrosła do 143,1\% i w następnych latach utrzymała się na zbliżonym poziomie. Podobnie wartość produkcji sprzedaży po niewielkim załamaniu do 122,1\% w 2009 roku zwiększyła się do 122,1\%, a następnie wzrosła do $143,1 \%$ w 2011 roku i również utrzymywała się na zbliżonym poziomie. Systematycznie spadała dynamika pracujących w przemyśle do 102,1\% w 2012 roku. Natomiast wyrównanym tempem wzrostu odznaczała się wartość środków trwałych, których dynamika systematycznie rosła do $135,2 \% \mathrm{w} 2012$ roku.

W świetle dynamiki wybranych cech poziom krajowego potencjału przemysłowego wykazywał różne tendencje przemian. Sytuacja kryzysowa najsilniej wpłynęła na osłabienie dynamiki pracujących, co oznacza, że w przedsiębiorstwach redukcja zatrudnienia była jednym z pierwszych działań zmierzających do ograniczenia trudności finansowych. Następnym działaniem było ograniczenie nakładów inwestycyjnych, które również doraźnie poprawiają kondycję finansową przedsiębiorstwa. W wyniku pewnej inercji utrzymuje się stały wzrost wartości środków trwałych, na co wpływa kumulowanie jej wartości z lat sprzed kryzysu. Głównym czynnikiem umożliwiającym rozwój przedsiębiorstwa jest wzrost wartości sprzedaży, która może się wahać nie tylko w wyniku ograniczenia chłonności rynku, ale także zmniejszania wartości zysku, a nawet sprzedaży, poniżej kosztów wytwarzania w celu utrzymania rynku. Zależy to w głównej mierze od oszczędności i zasobów wolnych środków finansowych, którymi przedsiębiorstwo może pokryć ewentualne straty. Natomiast zredukowanych pracowników w przedsiębiorstwie zastępują zwykle nowe maszyny i urządzenia pozwalające na zwiększoną wydajność pracy, a także zmiany organizacyjne.

$\mathrm{Na}$ gruncie nauk geograficznych w dotychczasowych analizach przemian struktury przemysłu posługujemy się najczęściej liczbą pracowników, która określa nam potencjał przemysłowy tylko od strony rynku pracy. W pracach badawczych konieczne wydaje się podejmowanie prób zastosowania także innych mierników potencjału przemysłowego. Należy jednak zaznaczyć, że poziom zatrudnienia pozostanie nadal ważnym miernikiem 
społeczno-ekonomicznym. W bezpośrednim stopniu wpływa on bowiem na jakość i poziom życia, które są podstawowym celem gospodarowania.

\section{UPADEOŚĆ PRZEDSIĘBIORSTW}

W latach transformacji gospodarowania i wdrażania reguł gospodarki rynkowej oraz nasilającego się kryzysu gospodarczego wiele przedsiębiorstw traci swoją pozycję konkurencyjną, a wraz z nią dotychczasowe rynki zbytu. Pociąga to za sobą pojawienie się trudności finansowych, które wpływają na utratę płynności finansowej, a następnie prowadzą do upadłości przedsiębiorstw (Kuciński, 2005). Największe nasilenie upadłości przedsiębiorstw nastąpiło się w latach 1997-2003, w okresie transformacji gospodarki, wówczas nastąpił gwałtowny wzrost upadłości przedsiębiorstw z 794 do 1863, czyli do 226,4\%. Upadały przedsiębiorstwa, które w nowych warunkach nie mogły sprostać konkurencji krajowej, a także zagranicznej, w wyniku m.in. otwierania się gospodarki na otoczenie międzynarodowe. Jedną z poważniejszych przyczyn niskiej konkurencyjności oferowanych produktów był także w latach 80 . XX wieku poważny spadek nakładów inwestycyjnych i odnowy majątku przemysłowego. $\mathrm{W}$ znacznym stopniu wynikało to z przesłanek politycznych oraz stwarzanych przez kraje zachodnie barier w zakresie powiązań gospodarczych, często pod wpływem krajowych ośrodków opozycji politycznej.

Tab. 4. Upadłości przedsiębiorstw w Polsce w latach 1997-2012

\begin{tabular}{|c|c|c|}
\hline Lata & Liczba upadłości & Dynamika \\
\hline 1997 & 794 & 100,0 \\
\hline 1998 & 864 & 108,8 \\
\hline 1999 & 1017 & 128,1 \\
\hline 2000 & 1289 & 162,3 \\
\hline 2001 & 1674 & 210,8 \\
\hline 2002 & 1863 & 234,6 \\
\hline 2003 & 1798 & 226,4 \\
\hline 2004 & 1163 & 146,5 \\
\hline 2005 & 861 & 108,4 \\
\hline 2006 & 648 & 81,6 \\
\hline 2007 & 480 & 60,5 \\
\hline 2008 & 425 & 53,5 \\
\hline 2009 & 673 & 84,8 \\
\hline 2010 & 691 & 87,0 \\
\hline 2011 & 730 & 91,9 \\
\hline 2012 & 877 & 110,5 \\
\hline
\end{tabular}

Źródło: dane z raportu Coface nt. upadłości firm w Polsce, Warszawa, 2 stycznia 2013 r. 
W latach 2002-2008 proces ten wykazywał tendencje spadkowe, w wyniku czego liczba upadających przedsiębiorstw zmniejszyła się z 1863 do 425 (tab. 4). Upadały przedsiębiorstwa, które przetrwały poprzedni system gospodarowania, oraz nowe podmioty gospodarcze, które również traciły swoje możliwości rozwojowe. Ponowne nasilenie upadłości zaznacza się w latach 2008-2012, a ich liczba zwiększyła się z 425 do 941. Podstawowy wpływ na ten proces wywarły: ograniczanie rozmiarów rynku związanego ze zmniejszaniem strumieni finansowych płynących do gospodarstw domowych, ograniczenia finansowe instytucji, nasilające się zatory płatnicze, które ograniczały płynność finansową przedsiębiorstw, a także znaczny napływ tanich produktów z zagranicy, m.in. poprzez międzynarodowe sieci handlowe, np. wyrobów odzieżowych, obuwniczych, elektrotechnicznych oraz produktów używanych (w tym samochodów, obuwia i odzieży). Oznacza to, że kryzys w gospodarce krajowej, w stosunku do krajów zachodnich, przesunął się w czasie.

Nasilenie kryzysu gospodarczego w różnym zakresie wpłynęło na poszczególne branże i sektory gospodarki. W latach 2010-2011 zaznacza się mniejszy spadek upadłości przedsiębiorstw przemysłowych, z 250 do 218 , czyli do 90,8\%, po czym w latach 2011-2012 nasilił się on z 218 do 227, czyli do 104,1\% (tab. 5). Upadłość w najmniejszym stopniu dotyczyła przedsiębiorstw produkujących wyroby z drewna, gumy i tworzyw sztucznych oraz metale i wyroby metalowe, czyli wytwarzających mniej skomplikowane wyroby, bardziej pracochłonne oraz związane ze stosunkowo niskimi cenami krajowych surowców. Upadek przedsiębiorstw odzieżowych i poligraficznych związany był z ograniczanym popytem krajowym, w wyniku nasilania oszczędności gospodarstw domowych (zmniejszyły się zakupy nowej odzieży, a także prasy, czasopism i książek). Nadto ważnym czynnikiem był import taniej odzieży oraz maszyn i urządzeń elektrotechnicznych wytwarzanych w krajach azjatyckich, zarówno przez przedsiębiorstwa krajowe, jak i zagraniczne. Równocześnie krajowe przedsiębiorstwa odzieżowe i obuwnicze przenosiły swoje oddziały produkcyjne do krajów azjatyckich o niskich kosztach pracy. Upadłość przedsiębiorstw budowlanych, podobnie jak przedsiębiorstw surowców mineralnych, związana jest głównie z trudnościami w zakresie budowy autostrad. Wynikały one w przeważającym stopniu z narastających zatorów płatniczych, a w konsekwencji z niepokrywania należności przedsiębiorstwom za dostarczone materiały i wykonane prace.

W większym stopniu upadłość przedsiębiorstw zaznaczyła się w pozostałych sektorach gospodarki. Upadłość sektora działalności naukowo-technicznej, do 170\%, była wynikiem braku wsparcia ze strony państwa rozwoju prac badawczo-rozwojowych oraz zakup przez przedsiębiorców licencji firm zagranicznych. Przewagą dostawców zagranicznych były gwarancje serwisowe na oferowane urządzenia, co czyniło ich bardziej konkurencyjnymi w stosunku do krajowych ośrodków badawczych. Nadto dominujące w strukturze krajowej przedsiębiorstwa będące własnością korporacji zagranicznych wdrażały rozwiązania technologiczne wytwarzane w krajach siedzib zarządów korporacji, co znacznie ograniczyło rynek dla polskich instytucji naukowo-badawczych. Rynek ten mogą rozszerzyć przedsiębiorstwa krajowe wdrażające nowe osiągnięcia badawcze (np. produkcja grafemu). 
Tab. 5. Upadłość przedsiębiorstw wg branż w latach 2010-1012

\begin{tabular}{|l|r|r|r|c|c|}
\hline \multicolumn{1}{|c|}{ Branże } & 2010 & 2011 & 2012 & $\begin{array}{c}\text { Dynamika } \\
2010-2011\end{array}$ & $\begin{array}{c}\text { Dynamika } \\
2011-2012\end{array}$ \\
\hline Działalność przemysłowa & 250 & 218 & 227 & 90,8 & 104,1 \\
\hline w tym produkcja: & & & & & \\
\hline metali i metalowych wyrobów gotowych & 50 & 47 & 39 & 78,0 & 83,0 \\
\hline artykułów spożywczych i napojów & 35 & 34 & 37 & 105,7 & 108,8 \\
\hline odzieży i wyrobów tekstylnych & 28 & 15 & 23 & 82,1 & 153,3 \\
\hline maszyn i urządzeń elektrycznych & 16 & 17 & 22 & 137,5 & 129,4 \\
\hline mebli & 15 & 12 & 17 & 113,3 & 141,7 \\
\hline mineralne surowce & 20 & 6 & 14 & 70,0 & 233,3 \\
\hline poligrafia i reprodukcja & 15 & 10 & 14 & 93,3 & 140,0 \\
\hline wyrobów z drewna (poza meblami) & 23 & 22 & 11 & 47,8 & 50,0 \\
\hline wyrobów z gumy i tworzyw sztucznych & 15 & 21 & 11 & 73,3 & 52,4 \\
\hline pozostałe & 45 & 34 & 39 & 86,7 & 114,7 \\
\hline Handel & 147 & 180 & 208 & 141,5 & 115,6 \\
\hline w tym handel & & & & & \\
\hline hurtowy & 107 & 115 & 124 & 115,9 & 107,8 \\
\hline detaliczny & 25 & 46 & 67 & 268,0 & 145,7 \\
\hline Transport i gospodarka magazynowa & 40 & 40 & 31 & 77,5 & 77,5 \\
\hline Budownictwo & 98 & 143 & 218 & 222,4 & 152,4 \\
\hline Obsługa rynku nieruchomości & 25 & 20 & 34 & 136,0 & 170,0 \\
\hline Działalność naukowa i techniczna & 83 & 94 & 122 & 147,0 & 129,8 \\
\hline Pozostałe branże & 723 & 877 & 133,9 & 121,3 \\
\hline Ogółem & 28 & 37 & 308,3 & 132,1 \\
\hline
\end{tabular}

Źródło: dane z raportu Coface nt. upadłości firm w Polsce, Warszawa, 2 stycznia 2013 r.

Na upadłość handlu detalicznego wpływały zmniejszające się strumienie finansowe płynące do gospodarstw domowych oraz zwiększanie oszczędności gospodarstw domowych wobec wizji nasilającego się kryzysu, zwłaszcza zmniejszania rozmiarów rynku pracy.

Proces upadłości przedsiębiorstw nasila się nadal. W 2013 roku upadły 883 kolejne przedsiębiorstwa, których łączne obroty sięgały 14,1 mld zł, a pracę straciło ponad 42,0 tys. pracowników. Wśród nich dominowały przedsiębiorstwa budowlane ${ }^{7}$. Upadło 198 firm, któ-

7 W bardzo trudnej sytuacji znajduje się także Kompania Węglowa, która w 2013 roku poniosła straty ok. 1 mld zł, w kwietniu 2014 roku brakowało jej $350 \mathrm{mln}$ zł na płace. Wpłynęło to na wstrzymanie przez tydzień eksploatacji. Należy wnosić, że biorąc pod uwagę koszty społeczne, rząd nie dopuści do upadłości. W trudnej 
rych roczny obrót sięgał 1,2 mld zł, a pracę straciło ponad 2,6 tys. osób. Kolejne pozycje zajmowały przedsiębiorstwa związane $\mathrm{z}$ działalnością finansową i ubezpieczeniową oraz produkcją maszyn i urządzeń.

W układach regionalnych proces upadłości przedsiębiorstw był zróżnicowany, a jego dynamika w latach 2011-2012 wahała się od 79,7\% do 188,9\%. Osłabienie tego procesu zaznaczyło się na terenie województwa małopolskiego, gdzie liczba upadających przedsiębiorstw zmniejszyła się do 79,7\%, łódzkiego (82,9\%) i zachodniopomorskiego $(91,4 \%)$. Natomiast upadłość najsilniej dotknęła tereny województw opolskiego, gdzie liczba upadających przedsiębiorstw zwiększyła się do $188,9 \%$, świętokrzyskiego $(177,8 \%)$, pomorskiego i wielkopolskiego (tab. 6).

Tab. 6. Upadłość polskich firm

\begin{tabular}{|c|c|c|c|c|c|}
\hline \multirow{2}{*}{ Województwa } & \multicolumn{2}{|c|}{ Liczba upadłości } & \multirow{2}{*}{$\begin{array}{c}\text { Dynamika } \\
2011-2012\end{array}$} & \multicolumn{2}{|c|}{ Struktura } \\
\hline & 2011 & 2012 & & 2011 & 2012 \\
\hline mazowieckie & 141 & 168 & 119,1 & 19,5 & 19,2 \\
\hline dolnośląskie & 87 & 110 & 126,4 & 12,0 & 12,5 \\
\hline wielkopolskie & 64 & 103 & 160,9 & 8,9 & 11,7 \\
\hline śląskie & 89 & 103 & 115,7 & 12,3 & 11,7 \\
\hline zachodniopomorskie & 70 & 64 & 91,4 & 9,7 & 7,3 \\
\hline małopolskie & 64 & 51 & 79,7 & 8,9 & 5,8 \\
\hline pomorskie & 29 & 47 & 162,1 & 4,0 & 5,4 \\
\hline kujawsko-pomorskie & 35 & 43 & 122,9 & 4,8 & 4,9 \\
\hline łódzkie & 35 & 29 & 82,9 & 4,8 & 3,3 \\
\hline lubelskie & 25 & 38 & 152,0 & 3,5 & 4,3 \\
\hline warmińsko-mazurskie & 18 & 28 & 155,6 & 2,5 & 3,2 \\
\hline podkarpackie & 23 & 25 & 108,7 & 3,2 & 2,9 \\
\hline podlaskie & 13 & 16 & 123,1 & 1,8 & 1,8 \\
\hline świętokrzyskie & 9 & 16 & 177,8 & 1,2 & 1,8 \\
\hline opolskie & 9 & 17 & 188,9 & 1,2 & 1,9 \\
\hline lubuskie & 12 & 19 & 158,3 & 1,7 & 2,2 \\
\hline ogółem & 723 & 877 & 121,3 & 100,0 & 100,0 \\
\hline
\end{tabular}

Źródło: raport Coface nt. upadłości firm w Polsce, Warszawa, 2 stycznia 2013 r.

Proces upadłościowy najsilniej zaznaczył się na terenie województw o najwyższym poziomie rozwoju, na obszarze województwa mazowieckiego ich liczba zwiększyła się ze 141

sytuacji finansowej znajduje się także duże przedsiębiorstwo budowlane Polimer-Mostostal, które w celu wygrania przetargu proponowało zbyt niskie ceny wykonawstwa inwestycyjnego. Najpoważniejszymi kredytodawcami są PKO BP i Bank Pekao należący do włoskiego banku UniCredit. Bank Pekao już w 2012 roku utrudniał możliwość zawarcia porozumień z wierzycielami, pomogło dopiero wstawienie się Ministerstwa Skarbu. Upadek tego przedsiębiorstwa odbił by się bardzo niekorzystnie na realizowanych przez niego pracach związanych z rozbudową elektrowni Opole i Kozienice, o łącznej wartości 14,5 mld zł. 
do 168, a ich udział wśród upadających przedsiębiorstw nieznacznie zmniejszył się z 19,5\% do 19,2\%. Kolejne pozycje zajmują województwa dolnośląskie, śląskie i wielkopolskie, na terenie których udział upadających przedsiębiorstw wzrósł z 33,2\% do 35,9\%.

Zarysowany proces wzrostu upadłości przedsiębiorstw wskazuje, że sytuacja kryzysowa w różnym stopniu wpływa na strukturę przestrzenną przemysłu krajowego. Największa upadłość zaznacza się na terenie województw o najwyższym poziomie rozwoju gospodarczego. Stwarzają one najkorzystniejsze warunki lokalizacji i rozwoju działalności przedsiębiorstw, na co wpływają chłonne rynki zbytu na oferowane produkty, tradycje przemysłowe, zagospodarowanie infrastrukturalne, większe możliwości kooperacyjne i nawiązania współpracy międzynarodowej. Umożliwia to powstanie wielu nowych przedsiębiorstw, które później nie mają szans dalszego rozwoju i upadają, co wynika często ze słabo przemyślanych decyzji ich lokalizacji.

Mniej korzystne warunki lokalizacji i rozwoju przedsiębiorstw mają obszary województw o niższym poziomie rozwoju. Wynika to z braku tradycji działalności przemysłowej i położenia z dala od europejskich i krajowych centrów wzrostu gospodarczego. Stąd zaznacza się na ich terenie mniej lokalizacji o większych możliwościach rozwojowych. Generalnie upadłość przedsiębiorstw w poszczególnych województwach nawiązuje do ich liczebności - im więcej przedsiębiorstw, tym większa liczba firm upadających.

\section{PRZEMIANY PRZEMYSŁOWEGO RYNKU PRACY}

Oznaki kryzysu gospodarczego, jak już wspomniano, najpierw uwidaczniają się w zmniejszaniu poziomu zatrudnienia, które w najszybszy i najprostszy sposób prowadzi doraźnie do polepszenia sytuacji finansowej przedsiębiorstw. Widać to także w zmianach struktury przestrzennej przemysłu krajowego w układach regionalnych (tab. 7). W latach przedkryzysowych (2005-2008) przeciętne zatrudnienie w przedsiębiorstwach przemysłowych systematycznie rosło z 2619,2 tys. osób do 2921,4 tys., czyli do 111,5\%, a latach kryzysu (2008-2012) zaznacza się wyraźny jego spadek do 2674,2 tys. osób, czyli do 91,5\%.

W latach 2005-2008 potencjał przemysłowy poszczególnych województw systematycznie się zwiększał. Najwyższe przyrosty zatrudnienia występowały w latach 2006-2007, od 101,8\% w województwie lubelskim do $107,0 \%$ w województwie lubuskim. Wyjątek stanowiło województwo mazowieckie, na terenie którego najpoważniejszy wzrost zatrudnienia utrzymywał się do 2006 roku (do 111,5\%) i warmińsko-mazurskie (do 193,8\%), co oznacza, że sytuacja kryzysowa na ich obszarze zaznaczyła się nieco wcześniej. Najpoważniejsze załamanie tej dynamiki nastąpiło w 2009 roku i wahało się od 88,2 w województwie podkarpackim do 97,0\% w województwie lubelskim. Nieznaczny wzrost zatrudnionych w niektórych województwach zaznaczył się dopiero w 2010 roku (lubelskie, lubuskie, łódzkie, małopolskie, warmińsko-mazurskie) i w 2011 roku. Natomiast w 2012 roku ponowna recesja zatrudnienia zaznaczyła się na terenie wszystkich województw, ale jej dynamika była mniej zróżnicowana i wahała się od 96,2\% w województwie świętokrzyskim do 99,6\% w województwie zachodniopomorskim. 


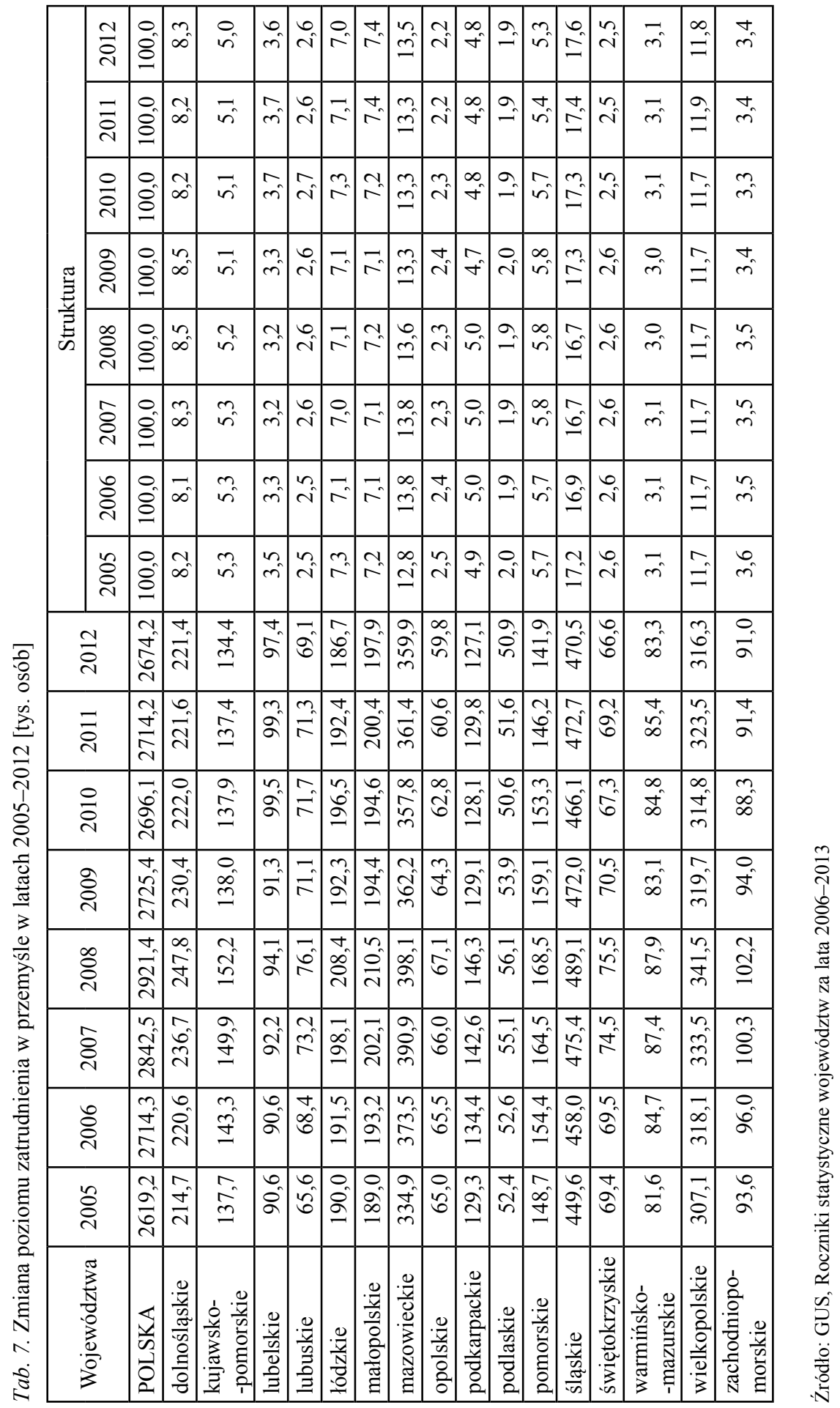


W latach 2005-2012 zmiany poziomu zatrudnienia w przemyśle krajowym odznaczały się różnymi tendencjami, w pierwszym okresie, w latach 2005-2008, przyrost ten wynosił 302,2 tys., natomiast w latach 2008-2012 nastąpił jego spadek o 247,2 tys., co w konsekwencji wpłynęło na niewielki przyrost zatrudnionych o 55,0 tys. osób.

W 2005 roku w układzie przestrzennym dominujące znaczenie pod względem poziomu zatrudnienia miało województwo śląskie, na terenie którego skupiało się 17,2\% zatrudnionych, a następnie województwo mazowieckie (12,8\% zatrudnionych), wielkopolskie $(11,7 \%)$ i dolnośląskie (8,2\%). Łącznie na obszarze tych czterech województw skupiał się znaczny potencjał przemysłowy, obejmujący 49,9\% ogólnego zatrudnienia.

$\mathrm{W}$ następnych latach systematycznie rósł udział województwa mazowieckiego do 13,5\% ogólnego zatrudnienia, co wynika z faktu, że zwłaszcza metropolia warszawska stawała się coraz bardziej atrakcyjna dla rozwijania działalności przemysłowej. Znaczny wpływ na ten stan wywarły funkcje stołeczne miasta, zasoby wysokokwalifikowanych kadr pracowniczych, łatwość nawiązania powiązań kooperacyjnych z przedsiębiorstwami międzynarodowymi, relatywnie sprawna infrastruktura techniczno-ekonomiczna i społeczna. W województwie śląskim do 2008 roku udział zatrudnionych spadał do 16,7\%, a następnie zwiększał się do $17,6 \%$ w 2012 roku. Znaczny wpływ na wzrost zatrudnienia w województwie śląskim miał czynnik polityczny, dbający, by nie doprowadzić do recesji całej gospodarki tego województwa oraz pogarszania warunków życia i nastrojów społecznych (Tkocz, 2001). Przejawiło się to w dofinansowaniu wielu istniejących i nowych lokalizacji przemysłowych, by utrzymać kurczący się rynek pracy ${ }^{8}$. Na zbliżonym poziomie utrzymało swój udział w potencjale przemysłowym województwo wielkopolskie, od 11,7\% do 11,9\% krajowego zatrudnienia. Wynika to z wielu działań władz samorządowych stwarzających korzystne warunki dla rozwoju przedsiębiorczości oraz bliskość zachodnioeuropejskich centrów wzrostu gospodarczego. W podobnej sytuacji znajdował się obszar województwa dolnośląskiego, które charakteryzuje się w miarę stabilnym udziałem zatrudnienia w przemyśle krajowym. Łącznie udział tych czterech województw w potencjale przemysłowym jest znaczny i w latach 2005-2012 zwiększył się z 49,9\% do 51,2\%.

Znaczący potencjał przemysłowy skupiony jest na terenie województwa łódzkiego małopolskiego, pomorskiego i kujawsko-pomorskiego, które odznaczały się niewielkim spadkiem udziału zatrudnienia w przemyśle krajowym, od 25,4\% do 24,7\%.

Malejącym udziałem potencjału przemysłowego z $24,7 \%$ do $24,1 \%$ charakteryzowało się pozostałych osiem województw o najniższym poziomie zatrudnienia.

Generalnie można przyjąć, że kryzys gospodarczy w zbliżonym stopniu oddziaływał na układy regionalne krajowej struktury przestrzennej przemysłu. Podkreślają to stosunkowo niskie wskaźniki redystrybucji przestrzennej, które w latach 2005-2008 wynosiły 0,014, a w latach 2008-2012 - 0,011, natomiast w całym okresie lat 2005-2012-0,017. Oznacza to, że na przemiany te w decydującym stopniu wpływały czynniki otoczenia międzynarodowego,

${ }^{8}$ Znaczny wpływ na ten stan ma m.in. wzrost przeciętnej ceny 1 tony węgla kamiennego, który wzrósł z 523 zł w 2007 roku do 810 zł w 2013 roku. Wydaje się, że w znacznym stopniu wynika to z wadliwego sytemu zarządzania tym sektorem przemysłu oraz dużymi marżami pośredników funkcjonujących między kopalniami a rynkiem (Madeja, 2014). 
co związane jest z coraz większym otwieraniem się krajowej gospodarki na otoczenie światowe. Oddziaływanie czynników krajowych dokonałoby znacznie większych zróżnicowań struktury przestrzennej, co uwidaczniało się bardzo wyraźnie w latach gospodarki centralnie sterowanej.

W krajowej strukturze przestrzennej kryzys gospodarczy w zakresie przemysłowego rynku pracy najsilniej zaznaczył się w 2009 roku, w latach 2010-2011 zaistniały pewne możliwości wychodzenia z niego, ale ponownie kryzys nasilił się w 2012 roku. Można wnosić, że taka sytuacja może się utrzymać także w najbliższych latach. Zmienić ją mogą zagraniczne korporacje, które wykorzystując relatywnie tanią i dobrze wykształconą siłę roboczą, zintensyfikują dotychczasowe i stworzą nowe lokalizacje swojej działalności (Madey, 2014). Powinny temu towarzyszyć także działania polityki pobudzającej rozwój krajowych przedsiębiorstw, np. związanych z sektorem obronnym.

Na kierunki przemian struktury przestrzennej przemysłu znaczny wpływ wywierają przedsiębiorstwa będące własnością kapitału zagranicznego. Wśród 500 największych krajowych przedsiębiorstw (wg listy dziennika „Rzeczpospolita”) ich liczba zwiększyła się z 253 w 2006 roku do 270 w 2012 roku i spadła do 258 w 2013 roku. Wzrosła także w tym czasie liczba krajowych przedsiębiorstw prywatnych, ze 150 do 202, a zmniejszyła się liczba przedsiębiorstw państwowych z 91 do 34. Firmy zagraniczne i prywatne krajowe rządzą się regułami mikroekonomicznymi i poszukują możliwości zwiększania zysku. Stąd - w zależności od uwarunkowań - wykazują one często tendencję do przenoszenia produkcji i usług do krajów o niższych kosztach produkcji i większych możliwościach zwiększenia efektów ekonomicznych firmy. Odnosi się to zwłaszcza do firm będących własnością kapitału zagranicznego, na które pewien wpływ, szczególnie w okresie kryzysu, wywierają także rządy krajów macierzystych, na terenie których znajdują się siedziby zarządów ${ }^{9}$. Natomiast przedsiębiorstwa państwowe, obok reguł mikroekonomicznych, uzależnione są od reguł makroekonomicznych, związanych z realizacją także celów społecznych. Często obarczane są dodatkowymi obciążeniami finansowymi na te cele. Ponadto znaczny udział przedstawicieli załóg w związkach zawodowych i radach nadzorczych (które reprezentują ludzie nie zawsze odpowiednio przygotowani do zarządzania firmami, a zasiadanie w nich stanowi pewną rekompensatę za utracone stanowiska), a także nie zawsze identyfikujące się z przedsiębiorstwem kierownictwo, w znacznie mniejszym stopniu wpływają na obniżanie efektów ekonomicznych. Dlatego wielu przedstawicieli biznesu kładzie nacisk na konieczność dalszego liberalizowania gospodarki poprzez prywatyzację tej kategorii przedsiębiorstw.

${ }^{9}$ Znane jest przeniesienie produkcji samochodów Panda na teren Włoch, pomimo że w Polsce produkcja była bardziej efektywna ze względu na koszty pracy i jakość produktów. Podobnie wywierane były naciski rządu Francji na przeniesienie produkcji samochodów z Rumunii na jej teren. Działania te miały głównie na celu stworzenie nowych miejsc pracy na terenie krajów siedzib zarządów, a ich likwidację na terenie krajów dotychczasowej produkcji. 


\section{UWAGI KOŃCOWE}

Zarysowany model podkreśla, że kształtowanie struktury przestrzennej przemysłu jest procesem bardzo złożonym. Tworzące ją przedsiębiorstwa przemysłowe oraz relacje zachodzące między nimi odznaczają się bardzo dużym zróżnicowaniem pod względem potencjału ekonomicznego oraz spełnianych funkcji w przestrzeni gospodarczej. Relacje te określają różnorodne powiązania produkcyjne, usługowe, zaopatrzeniowe, kooperacyjne, finansowo-kapitałowe i in. W zasadniczym stopniu rozwój działalności uzależniony jest od zmieniającej się sytuacji rynkowej, która stwarza określone zapotrzebowanie na dane produkty, a także celowych zamówień publicznych. Na procesy kształtowania struktury przestrzennej przemysłu w znacznym stopniu wpływa sytuacja ekonomiczna różnej skali układów przestrzennych, wśród której szczególne znaczenie ma zmienność chłonności rynku przez podmioty gospodarcze reprezentowane przez przedsiębiorstwa przemysłowe, instytucje i gospodarstwa domowe. $\mathrm{W}$ rozszerzaniu rynku podstawowe znaczenie ma wzrost konkurencyjności produktów wyrażający się ich ceną, nowoczesnością i własnościami użytkowymi. W kształtowaniu działalności przedsiębiorstw najistotniejsze jest dążenie do maksymalizacji efektów ekonomicznych oraz osiąganie znaczącej pozycji na konkurencyjnym rynku.

Przemiany struktury przestrzennej przemysłu dokonują się także pod wpływem warunków otoczenia, które reprezentują pozostałe sektory gospodarki, instytucje finansowe i publiczne, a także uwarunkowania związane z zasobami finansowymi podmiotów gospodarczych, przyjmowane reguły rozwoju ekonomicznego (stopień centralizacji lub liberalizacji gospodarki) oraz związana z nimi polityka gospodarcza, społeczna i kulturowa.

Szczególnie silne zmiany w tym zakresie zaznaczają się w latach kryzysu gospodarczego, który zaburza wykształcone wcześniej sieci powiązań produkcyjnych, gospodarczych, społecznych i kulturowych oraz układów rynkowych. W różnym stopniu wpływają one na przedsiębiorstwa przemysłowe i przejawiają się w ich zanikaniu, stagnacji, rozwoju lub pojawianiu się nowych przedsiębiorstw.

W wyniku postępu naukowo-technicznego i organizacyjnego następuje wzrost potencjału produkcyjnego i usługowego, który przyczynia się do podniesienia efektów ekonomicznych oraz ograniczania rozmiarów rynku pracy, co ma poważne konsekwencje dla rozwoju społecznego i kulturowego.

Przedsiębiorstwa przemysłowe funkcjonujące w strukturze przestrzennej przemysłu spełniają w niej różne funkcje. Podstawową rolę odgrywają przedsiębiorstwa o funkcjach światowych, międzynarodowych i krajowych, odznaczające się znaczącym potencjałem ekonomicznym i technicznym. Poprzez różnego rodzaju relacje stanowią ważne czynniki rozwoju przedsiębiorstw o funkcjach komplementarnych, regionalnych i lokalnych.

W warunkach globalizacji i internacjonalizacji produkcji na krajową strukturę przestrzenną przemysłu w znacznym stopniu wpływają przedsiębiorstwa zagraniczne oraz prywatne przedsiębiorstwa krajowe, natomiast maleje udział w tej strukturze przedsiębiorstw państwowych. Ma to swoje konsekwencje w przyjmowanych celach i formach zarządzania oraz różnych możliwościach wpływu krajowej polityki gospodarczej na procesy przemian. 
Stąd wydaje się, że zaproponowane ujęcie modelowe otwiera nowe pola badawcze związane z koniecznością dalszego pogłębiania badań nad funkcjonowaniem przedsiębiorstw w nowych uwarunkowaniach gospodarki krajowej, w strukturach Unii Europejskiej, a także gospodarki światowej.

\section{Literatura \\ References}

Baj, L. (2013). Polskie buraki kontra niemieckie procesory. Nasza praca i płaca. Gazeta Wyborcza, 9 września.

Boguś, M. (2011). Dynamika potencjału ekonomicznego korporacji ponadnarodowej Google w latach 2001-2009. Prace Komisji Geografii Przemystu Polskiego Towarzystwa Geograficznego, 17, $212-224$.

Bonar, P. (2011). Funkcjonowanie korporacji Ericsson w warunkach globalnego kryzysu gospodarczego, Prace Komisji Geografii Przemystu Polskiego Towarzystwa Geograficznego, 17, 197-211.

Domański, B. (2001). Kapitał zagraniczny w przemyśle Polski. Kraków: Uniwersytet Jagielloński, Instytut Geografii i Gospodarki Przestrzennej.

Dziewoński, K. (1946). Zagadnienia zespołu produkcyjnego w teorii lokalizacji i praktyce planowania, Ekonomista, 3.

Fajferek, A. (1966). Region ekonomiczny i metody analizy regionalnej. Warszawa: PWE.

Florecie, P.S. (1965). Brytyjski i amerykański system przemystowy. Warszawa: PWE.

Kalecki, M. (1979). Teoria dynamiki gospodarczej. W: Dzieła, t. 2, Warszawa: PWE.

Keynes, M.J. (1956). Ogólna teoria zatrudnienia, procentu i pieniądza. Warszawa: PWE.

Kilar, W. (2009a). Koncentracja przestrzenna światowych firm informatycznych. Prace Komisji Geografii Przemystu Polskiego Towarzystwa Geograficznego, 12, 97-108.

Kilar, W. (2009b). Rola korporacji Apple w kształtowaniu społeczeństwa informacyjnego. Przedsiębiorczość - Edukacja, 5, 48-56.

Kilar, W. (2010). Procesy kształtowania korporacji Ericsson. Prace Komisji Geografii Przemystu Polskiego Towarzystwa Geograficznego, 16, 153-169.

Kilar, W. (2011). Wpływ kryzysu na funkcjonowanie korporacji Panasonic. Prace Komisji Geografii Przemystu Polskiego Towarzystwa Geograficznego 17, 187-196.

Kleer, J. (2013). Kryzys finansowy a kryzys cywilizacyjny. W: S. Lis, A. Prusek (red.). Europa wobec wyzwań kryzysu finansowego. Dylematy polityki społeczno-ekonomicznej. Kraków: Uniwersytet Ekonomiczny w Krakowie, 33-55.

Kołodko, G. (2008). Wędrujący świat. Warszawa: Pruszyński i S-ka.

Kuciński, K. (red.) (2003). Polskie przedsiębiorstwa wobec standardów europejskich, t. LXXXIV. Warszawa: Instytut Funkcjonowania Gospodarki Narodowej SGH.

Kuciński, K. (red.) (2004). Polskie przedsiębiorstwa wobec szoku akcesyjnego, t. LXXXVIII. Warszawa: Instytut Funkcjonowania Gospodarki Narodowej SGH.

Kuciński, K. (red.). (2005). Zagrożenie upadłościa, t. XCIII. Warszawa: Instytut Funkcjonowania Gospodarki Narodowej SGH.

Kukliński, A. (1954). Zakład przemysłowy w uniwersyteckim nauczaniu geografii. Czasopismo Geograficzne, 4.

Madeja, J. (2014). Górnictwo woła o pomoc. Gazeta Wyborcza, 7 maja.

Madey, J. (2014). Wyrośliśmy na informatyczną potęgę. Gazeta Wyborcza, 24 kwietnia.

Misztal, S. (1962). Warszawski Okręg Przemysłowy. Studia Komitetu Przestrzennego Zagospodarowania Kraju PAN, IV. 
Misztal, S. (1970). Przemiany struktury przestrzennej przemysłu Ziem Polskich w latach 1960-1965. Studia Komitetu Przestrzennego Zagospodarowania Kraju PAN, XXXI.

Pakuła, L. (1965). Kształtowanie i struktura Zachodnio-Krakowskiego Okręgu Przemysłowego. Biuletyn Komitetu Przestrzennego Zagospodarowania Kraju PAN, seria A, 2.

Pakuła, L. (1973). Procesy aglomeracyjne i integracyjne przemysłu w obrzeżu Górnośląskiego Okręgu Przemysłowego. Prace monograficzne WSP w Krakowie, IX.

Rachwał, T. (2003). Globalne uwarunkowania restrukturyzacji przedsiębiorstw Polski Południowo-Wschodniej. Prace Komisji Geografii Przemystu Polskiego Towarzystwa Geograficznego, 6, $129-138$.

Rachwał, T. (2011). Wpływ kryzysu na zmiany produkcji przemysłowej w Polsce. Prace Komisji Geografii Przemystu Polskiego Towarzystwa Geograficznego, 17, 99-113.

Secomski, K. (1956). Wstęp do teorii rozmieszczenia sił wytwórczych. Warszawa: PWG.

Smith, A. (1954). Badania nad natura i przyczynami bogactwa narodów. Warszawa: PWN.

Soros, G. (2008). Kryzys finansowy. Nowy paradygmat rynków finansowych i co to oznacza. Warszawa: PWN.

Szymański, W. (2001). Globalizacja. Wyzwania i zagrożenia. Warszawa: Difin.

Tkocz, M. (2001). Restrukturyzacja przemystu regionu tradycyjnego. Katowice: Wydawnictwo Uniwersytetu Śląskiego.

Wajda, E. (2003). Proces kształtowania się Motoroli jako firmy ponadnarodowej. Prace Komisji Geografii Przemystu Polskiego Towarzystwa Geograficznego, 86-114.

Wajda, E. (2006). Rozwój i struktura przestrzenna działalności Nokii w latach 1997-2003. Prace Komisji Geografii Przemystu Polskiego Towarzystwa Geograficznego, 8, 219-240.

Wajda, E., Zalewska, K. (2003). Struktura przestrzenno-organizacyjna korporacji General Motors. Prace Komisji Geografii Przemystu Polskiego Towarzystwa Geograficznego, 6, 119-127.

Wajda, E., Zoričič-Wołek, M. (2003). Proces kształtowania się korporacji IBM. Prace Komisji Geografii Przemystu Polskiego Towarzystwa Geograficznego, 6, 109-11.

Zioło, Z. (1970). Formy koncentracji przemysłu w strukturze przestrzennej województwa rzeszowskiego. Rocznik Naukowo-Dydaktyczny WSP w Krakowie, Prace Geograficzne, V, 273-295.

Zioło, Z. (1972). Próba konstrukcji wielomiernikowej mapy przemysłu. Polski Przegląd Kartograficzny, 4 (3), 127-133.

Zioło, Z. (1973a). Analiza powiązań przestrzenno-produkcyjnych Tarnobrzeskiego Okręgu Przemysłowego, II etap problemu węzłowego, nr 11.2.1. Podstawy przestrzennego zagospodarowania kraju, maszynopis Arch. IG PAN, Warszawa, 56.

Zioło, Z. (1973b). Analiza struktury przestrzennej i form koncentracji przemysłu województwa rzeszowskiego w świetle wybranych mierników. Folia Geographica, Series GeographicaOeconomica, VII, 30-55.

Zioło, Z. (1980a). Wplyw przemystu na rozwój społeczno-ekonomiczny regionu rzeszowskiego. Komitet Badań Rejonów Uprzemysławianych PAN. Warszawa: PWN.

Zioło, Z. (1980b). Założenia do budowy zarysu teorii geografii przemystu. Referat na konferencję nt. Geografia przemysłu jako dyscyplina naukowa. Teoretyczno-metodyczne problemy geografii przemysłu. Komisja Geografii Przemysłu PTG, Kraków 21-22 marca (maszynopis powielony).

Zioło, Z. (1997). Miejsce struktury przestrzennej przemysłu w przestrzeni geograficznej. W: Geografia, Człowiek, Gospodarka. Profesorowi Bronisławowi Kortusowi w 70 rocznice Urodzin. Kraków: Uniwersytet Jagielloński, 125-132.

Zioło, Z. (1999). Model funkcjonowania przestrzeni geograficznej jako próba integracji badań geograficznych. W: Geografia na przełomie wieków - jedność w różnorodności. Warszawa: Wydział Geografii i Studiów Regionalnych Uniwersytetu Warszawskiego, 122-131.

Zioło, Z. (2001). Struktura branżowa i koncentracja przestrzenna wiodących światowych firm przemysłowych. Prace Komisji Geografii Przemystu Polskiego Towarzystwa Geograficznego, 3, 29-41. 
Zioło, Z (2003a). Przestrzeń geograficzna jako miejsce realizacji idei ładu przestrzennego. Biuletyn Komitetu Przestrzennego Zagospodarowania Kraju PAN, 205, 25-43.

Zioło, Z. (2003b). Kształtowanie się przedsiębiorstw przemysłowych w procesie globalizacji. Prace Komisji Geografii Przemystu Polskiego Towarzystwa Geograficznego, 6, 9-20.

Zioło, Z. (2003c). Potencjał ekonomiczny światowego systemu finansowego i korporacji gospodarczych. W: S. Lis, A. Prusek (red.). Europa wobec wyzwań kryzysu finansowego. Dylematy polityki społeczno-ekonomicznej. Kraków: Uniwersytet Ekonomiczny w Krakowie, 56-73.

Zioło, Z. (2006). Zróżnicowanie światowej przestrzeni przemysłowej w świetle koncentracji siedzib zarządów wiodących korporacji. Prace Komisji Geografii Przemystu Polskiego Towarzystwa Geograficznego, 8, 9-26.

Zioło, Z. (2011). Wpływ światowego kryzysu na tempo wzrostu gospodarki i światowych korporacji. Prace Komisji Geografii Przemystu Polskiego Towarzystwa Geograficznego, 17, 9-32.

Zioło, Z. (2013). Uwarunkowania rozwoju przedsiębiorczości w warunkach kryzysu gospodarczego. Prace Komisji Geografii Przemystu Polskiego Towarzystwa Geograficznego, 9, 10-33.

Zioło, Z., Rachwał, T. (red.) (2011). Wpływ kryzysu na zachowanie przedsiębiorstw oraz przemiany struktur regionalnych. Prace Komisji Geografii Przemystu Polskiego Towarzystwa Geograficznego, 17, 5-6.

Zioło, Z., Rachwał, T. (red.), (2013). Rola przedsiębiorczości w warunkach kryzysu gospodarczego. Przedsiębiorczość - Edukacja, 9, 5-6.

Zbigniew Zioło, prof. dr hab., Uniwersytet Pedagogiczny im. Komisji Edukacji Narodowej w Krakowie, Instytut Geografii, Zakład Przedsiębiorczości i Gospodarki Przestrzennej. Doktor nauk przyrodniczych, dr hab. i profesor nauk ekonomicznych. Jego zainteresowania badawcze to: gospodarka przestrzenna, geografia ekonomiczna, polityka społeczno-gospodarcza, ekonomika i polityka rozwoju regionalnego.

Zbigniew Ziolo, professor, the Pedagogical University of Cracow, Institute of Geography, the Department of Entrepreneurship and Spatial Management. He holds a D.Sc. title. He is also a professor of Economics. His research interests include: land management, economic geography, socio-economic policies, economics and policies of regional development.

\section{Adres/address:}

Uniwersytet Pedagogiczny w Krakowie

Instytut Geografii

Zakład Przedsiębiorczości i Gospodarki Przestrzennej

ul. Podchorążych 2, 30-084 Kraków, Polska

e-mail: ziolo@up.krakow.pl 